\title{
GIS-Based Aesthetic Appraisal of Short-Range Viewsheds of Coastal Dune and Forest Landscapes
}

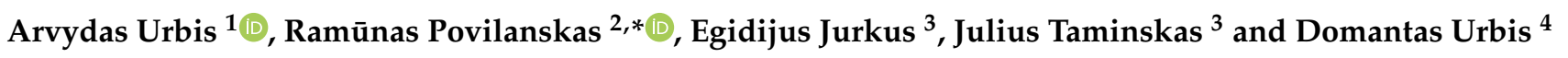 \\ 1 Department of Nature Sciences, Klaipeda University, 84 Herkaus Manto Str., LT-92294 Klaipeda, Lithuania; \\ arvydas.urbis@ku.lt \\ 2 Department of Sport, Recreation and Tourism, Klaipeda University, 84 Herkaus Manto Str., \\ LT-92294 Klaipeda, Lithuania \\ 3 Laboratory of Climate and Water Research, Nature Research Centre, 2 Akademijos Str., \\ LT-08412 Vilnius, Lithuania; egis.jurkus@gamtc.lt (E.J.); julius.taminskas@gamtc.lt (J.T.) \\ 4 College of Engineering and Computer Science, University of Central Florida, 4000 Central Florida Blvd, \\ Orlando, FL 32816, USA; domantasurbis@gmail.com \\ * Correspondence: ramunas.povilanskas@gmail.com; Tel.: +370-6157-1711
}

check for updates

Citation: Urbis, A.; Povilanskas, R.; Jurkus, E.; Taminskas, J.; Urbis, D. GIS-Based Aesthetic Appraisal of Short-Range Viewsheds of Coastal Dune and Forest Landscapes. Forests 2021, 12, 1534. https://doi.org/ $10.3390 /$ f12111534

Academic Editor: Seong-il Kim

Received: 27 September 2021

Accepted: 2 November 2021

Published: 7 November 2021

Publisher's Note: MDPI stays neutral with regard to jurisdictional claims in published maps and institutional affiliations.

Copyright: (c) 2021 by the authors. Licensee MDPI, Basel, Switzerland. This article is an open access article distributed under the terms and conditions of the Creative Commons Attribution (CC BY) license (https:// creativecommons.org/licenses/by/ $4.0 /)$.

\begin{abstract}
This paper demonstrates the possibilities of a Geographical Information System (GIS) for investigating and explicating the spatial variation of the short-range viewshed aesthetic appeal in a World Heritage coastal dune and forest area. The study pursues the following objectives: (1) develop and trial a GIS-based algorithm for computing the Aesthetic Appeal Index for a Short-Range Viewshed $(\bar{x})$; (2) deliver an output map showing the spatial variation of the computed $\bar{x}$ values in the target territory and distribution of the zones with high scenic quality and potential aesthetic ecosystem services (PAES); and (3) assess management alternatives in zones with high PAES and high conservation value. This study combines two key innovative aspects. First, it integrates an objective digital map of habitats with subjective scenic preferences of coastal forest and dune landscapes based on psychophysical and cognitive perceptions of scenic beauty. Second, it applies a GIS-based algorithm to translate subjective scenic preferences to an output map of $\bar{x}$. The study's main conclusion is that the combined aesthetic appraisal of the immediate and foreground viewshed of coastal forests and dunes, by applying a specially created GIS algorithm, allows an assessment of the scenic quality of this landscape reliably in statistical terms.
\end{abstract}

Keywords: aesthetic appraisal; aesthetic ecosystem services; Baltic Sea; coastal dunes; coastal forests; GIS; short-range viewshed

\section{Introduction}

The aim of this study is to demonstrate the possibilities of a Geographical Information System for investigating and explicating the geographical variation of the aesthetic appeal of a UNESCO-listed coastal dune and forest landscape, interpreted in psychophysical and cognitive terms as Potential Aesthetic Ecosystem Services (PAES). Landscape perceptions result from the transactions between individuals and landscapes [1]. Experts have argued for many years that considering the public's aesthetic perceptions, judgments, needs, and demands could contribute to more effective and intelligent landscape planning and wiser resource use [2]. What is needed for that purpose is a visual aesthetic assessment of the geographic and temporal patterns of environmental conditions [3].

The role of aesthetic resources in the economic valuation of natural and semi-natural landscapes has increased in recent decades [4-7]. Currently, the research on the scenic quality and aesthetic value of landscapes, particularly those with a high recreational appeal, mainly focuses on aesthetic ecosystem services (AES) as part of a broader sphere of cultural ecosystem services (CES). Booth et al. [8] and Schirpke et al. [9] focus on modelling the scenic value of various regions in the USA and Europe as an essential component of AES (former) and CES (latter). 
Bubalo et al. [10] and Goldberg [11] apply crowdsourced geo-information to map aesthetic landscape preferences and CES. Mederly and Černecký [12] elicit and analyze three types of CES:

1. Recreation and tourism: physical use of nature and landscape;

2. Landscape aesthetics: aesthetic values;

3. Natural and cultural heritage: intellectual and scientific values.

However, Raumer et al. [13] argue that a CES approach separates aesthetics and recreation, impeding deeper insights into landscape research. Gosal and Ziv [14] and Kalinauskas et al. [15] concur, arguing that aesthetic values of landscapes interpreted as CES are context-specific and difficult to assess, generalize, and validate spatially. Hence, visual resources are a critical but often ignored type of CES [11]. On the other hand, Povilanskas et al. [16] and Urbis et al. [17,18] argue that, if properly assessed and interpreted, AES and CES could deliver technical tools for landscape conservation and management on the local and regional levels.

Traditionally, two contrasting approaches-'objectivist' and 'subjectivist' - have dominated methodology development in landscape aesthetics $[19,20]$. They delineate a crucial methodological divide concerning the answer to the critical question: "Is scenic quality an objective property inherent in the landscape or a subjective impression based on individual cognitive processes?" [19]. In other words, one approach presupposes that scenic quality is inherent in the actual setting, while the second approach assumes that scenic quality is "in the eyes of the beholder" [19-21].

Adherents of the objectivist (ecological/physical/formal aesthetic) paradigm characterize the landscape as an object. Consequently, descriptive inventories usually rely on the judgments and standards held by trained and skilled experts. This approach asserts that professionals can objectively determine the public's preferences with enough expertise without asking the public. Most scenic quality assessments conducted by forest and land management institutions worldwide maintain the objectivist paradigm. On the other hand, the "subjectivist" paradigm relies on scenic preferences resulting from the physical characteristics of the landscape in question, and the attitudes, expectations or perceptions of the observing individuals.

The subjective approach represents the perspective that the focus of a study is the individual perceiver, not the landscape itself. From the subjectivist viewpoint, the 'scenery' exists only as the individuals under scrutiny perceive it. Personal perception is the cornerstone of the "subjectivist" paradigm, with internalized attitudes and values comprising the units of study [22]. In other words, a perception-based approach emphasizes the human (subjective) view of the landscape and treats its biophysical features as stimuli that evoke relevant psychological responses. The subjectivist paradigm considers scenic quality as a human construct.

Such a human construct is based on the interpretation of what an observer perceives through memories, associations, imagination and any symbolism it evokes [19]. In perception-based assessments, the context implies that ecological objectives (e.g., diversity, sustainability) are not definable at any specific point but require consideration of a changing spatial mosaic of different environmental conditions. Determining relationships between the ecological quality and visual aesthetic quality of the landscape, then, must address a dynamic kaleidoscope of conditions that naturally and continually change in response to ecosystem processes [3].

In technical terms, the main difference between the 'objectivist' and 'subjectivist' approaches may be summarized as follows. The aesthetic valuation in the objectivist paradigm relies on the ecological, geographical and architectural criteria of the visual landscape units according to the structural and physiological principle of the scenic expression. Only suitably qualified experts can carry out such an assessment. The objectivist aesthetic valuation indicators determine the aesthetic appeal of the landscape based on the structure of individual spaces (open vs. closed, expressive vs. monotonous), and the ratio of various landscape elements (forested or urban spaces, water bodies, balmy microclimate). The 
obtained result is typically a comprehensive study describing many different parameters of landscape elements (forest cover, forest quality, visual transparence, the composition of visual elements and lines, forest age and structure).

The subjectivist aesthetic valuation relies on an emotional reaction to the scenic view here and now or its fixed photographic or IT-simulated image. In order to achieve reliable results, the research aims to address as many people as possible with different perspectives. Based on this paradigm, the methods of aesthetic-emotional assessment of the landscape reflect the dynamics of the variable aesthetic value of the society (community), depending on the user. The result obtained is presented in free emotional visual image descriptions or breakdowns according to the predicted emotional response scale. The scalability of the subjectivist aesthetic valuation is negligible; as the scale changes, the assessment changes little.

After scrutinizing 134 studies published between 2015 and 2021, we conclude that the objectivist paradigm primarily addresses the issues of landscape valorization on the national or regional scale $[15,23]$. In this way, it tends to overlook local landscape management units, which is a shortcoming of the objectivist approach. Meanwhile, the subjectivist paradigm emphasizes landscape perceptions by local people or visitors. In the age of social media, this may include a large group of virtual visitors, yet, the focus is still on local landscape units. Hence, the difficulty of scaling up results, generalizing and validating them is the main criticism of the subjectivist approach [15].

The psychophysical paradigm integrates 'objectivist' and 'subjectivist' approaches in the landscape aesthetics. It was accepted first in the USA [2,20,22,24-27], and later in Europe [16-18,28-32]. The psychophysical paradigm in the research of landscape perception relies on the relationship between the 'objective', material elements comprising the landscape and the 'subjective' observer's judgment [20].

The psychophysical functions have proven to be robust to changes of landscapes and observers [26]. Therefore, the psychophysical approach is fruitful in scenic quality research, which is pertinent to forest recreation, since a perennial question on the academic tourism research agenda is the understanding of the tourist [33], and hence also her or his landscape perceptions and preferences [21].

Furthermore, Vining and Stevens [2] argued for relating the physical environment and the observer's psychophysical perception with her cognitive structure. They saw no reason to separate the psychophysical and cognitive approaches in studying the relationship between the physical traits of the landscape and the resulting perceptual response of the observer, as the latter's response is a function of the cognitive process. Experiencing involves the processes of seeing, knowing, believing and recognizing. These processes are cognitive and are based on individuals' background knowledge, learning, and reasoning capabilities [34].

The human factors affecting scenic preference include education, personality, profession, involvement, and socio-cultural groupings [20,35]. Hence, integration of the psychophysical and cognitive paradigms implies that the aesthetic quality of the landscape is a product of an interaction between the individual viewer and the landscape in which the human component comprises experience, future expectations and the sociocultural context, and the landscape component includes individual elements, scenes and habitats as entities [31,34]. In other words, the landscape relates the individual to their environment [36,37].

Such a complex view of landscape perception acknowledges underlying cognitive processes, such as environmental attitudes or acceptability of an impact, as well as the observer's particular frame of reference, which mediates the response to a visual stimulus [22]. Therefore, in landscape preference studies, we have to express quantitatively meanings and attitudes associated with landscapes bearing salient societal connotations and complex management implications, i.e., semi-natural forest and dune landscapes with high recreational and heritage value, like the Curonian Spit $[38,39]$. 
Such perspectives may provide a robust foundation for more cognitive perceptions [40]. In cognitively and emotionally charged cases of conservation and management of highquality scenery, quantitative methods of analysis and demonstration of the landscape structure and image are needed [41]. An integrated approach, which focuses on the psychophysical and cognitive nature of human-landscape interactions and their outcomes (including preference, values, satisfaction, well-being, predictions, and physical landscape elements or habitats) prevails in the scrutinized literature.

Furthermore, considering the effects of the human-centered integrated approach towards interpretation of the aesthetic quality of landscapes, the biophilic effect should be noted as technically resulting from the psychophysical and cognitive approaches. It is a technical toolbox used within landscape architecture to enhance the beneficial relationship of both residents and visitors with the environment through nature, professionally designed landscapes and habitats, and also, place and space conditions. It is argued that the biophilic effect has evidence-based health benefits for residents and visitors in various aesthetically appealing recreational environments [42-44].

The interest in spatial data and GIS for assessing the scenic quality of natural and seminatural landscapes started in the 1980s. Early attempts to apply GIS for the scenic quality assessment already incorporated visual values in sustainable landscape planning [45]. According to an observation by Bishop and Hulse [46] (p. 60):

'If visual values can be predicted using mapped data and the computational capabilities of a GIS, then there exists the potential for development of more objective and cost-effective procedures for assessment of visual qualities and the impact of change'.

Applying GIS for scenic quality valuation of landscapes with a recreational potential became popular in the 2000s with the rapid advance of the computational capabilities of GIS software, including statistical analysis, visualization and computer modelling [47-49]. $\mathrm{Xu}$ et al. [50] analyzed 92 studies of cultural and ecological landscape corridors in Europe, published between 1990 and 2018, focusing on their planning and management, the problems addressed, approaches and tools used, spatial scales and the stakeholders involved. They found that GIS analysis-often together with cost-distance analysis, graph-based analysis and spatial network analysis—-was the most widely employed approach (82\% of the surveyed studies) for planning and managing landscape corridors.

GIS-based procedures to value AES and, more generally, CES result from linking process-based models with non-market economic valuation methods [51-53]. For example, many case studies worldwide explore a framework that combines GIS with the Hedonic Pricing Method in analyzing the relationship of the value of green and open spaces with housing prices [54-60]. Therefore, the main aim of our work is to explore the relationship between the scenic dimensions, such as naturalness, heterogeneity and succession, and public perception of the scenic quality of semi-natural forest and dune landscapes with high recreational and heritage value in a new and innovative way.

Our study comprises the full range of scenes representing all forest and dune habitats and landscapes-from forest plantations to the natural dune habitats of interest for the European Union NATURA 2000 series necessary for the protection of biodiversity.

The study pursues the following concrete objectives:

1. Create and trial a GIS-based algorithm for computing values of the Aesthetic Appeal Index for a Short-Range Viewshed $(\bar{x})$;

2. Deliver a GIS map showing the spatial variation of $\bar{x}$ values in the target territory and distribution of the zones with high scenic quality and, hence, Potential Aesthetic Ecosystem Services (PAES);

3. Assess management alternatives at the sites with extraordinary PAES and high conservation value, suggesting the best hiking routes in strict nature reserves;

4. Discuss the advantages and limitations of the methodology as a decision support process in coastal forest and dune management and tourism planning. 
This study features two innovative elements:

(1) Comprehensive analysis of scenic preferences for forest and dune landscapes in the immediate and foreground viewshed using a qualitative-quantitative combination of methods; and (2) creating and applying a valuation spreadsheet of the immediate and foreground habitat combinations of coastal forests and dunes and thus reducing the required hardware capacity and computation time. The study's main conclusion is that a combined valuation of the short-range, i.e., immediate and foreground viewshed of coastal forests and dunes on the Curonian Spit, applying an innovative GIS algorithm, allows assessment of the scenic quality of this series of habitats and landscapes reliably in statistical terms.

\section{Materials and Methods}

\subsection{Study Area}

The Curonian barrier spit separates the Curonian Lagoon from the open Baltic Sea (Figure 1). The length of the Curonian Spit is $94 \mathrm{~km}$ and the width varies from $380 \mathrm{~m}$ to $4 \mathrm{~km}$. It is the largest accumulative barrier sand spit in the Baltic Sea Region [61]. The varied and dynamic dune landscape with high biological diversity and a strong visual appeal is a distinctive feature of the Curonian Spit on a regional scale [62]. The 32.6-km long Great Curonian Dune Ridge of 40-60 m high mobile dunes is the longest coastal mobile dune ridge in Europe [63]. Politically, it is shared by Lithuania and Russia. The Curonian Spit extends from Zelenogradsk (Russia) in the southwest $\left(54^{\circ} 58^{\prime} \mathrm{N}, 20^{\circ} 30^{\prime} \mathrm{E}\right)$ to Kopgalis (Lithuania) in the northeast $\left(55^{\circ} 43^{\prime} \mathrm{N}, 21^{\circ} 06^{\prime} \mathrm{E}\right)$.

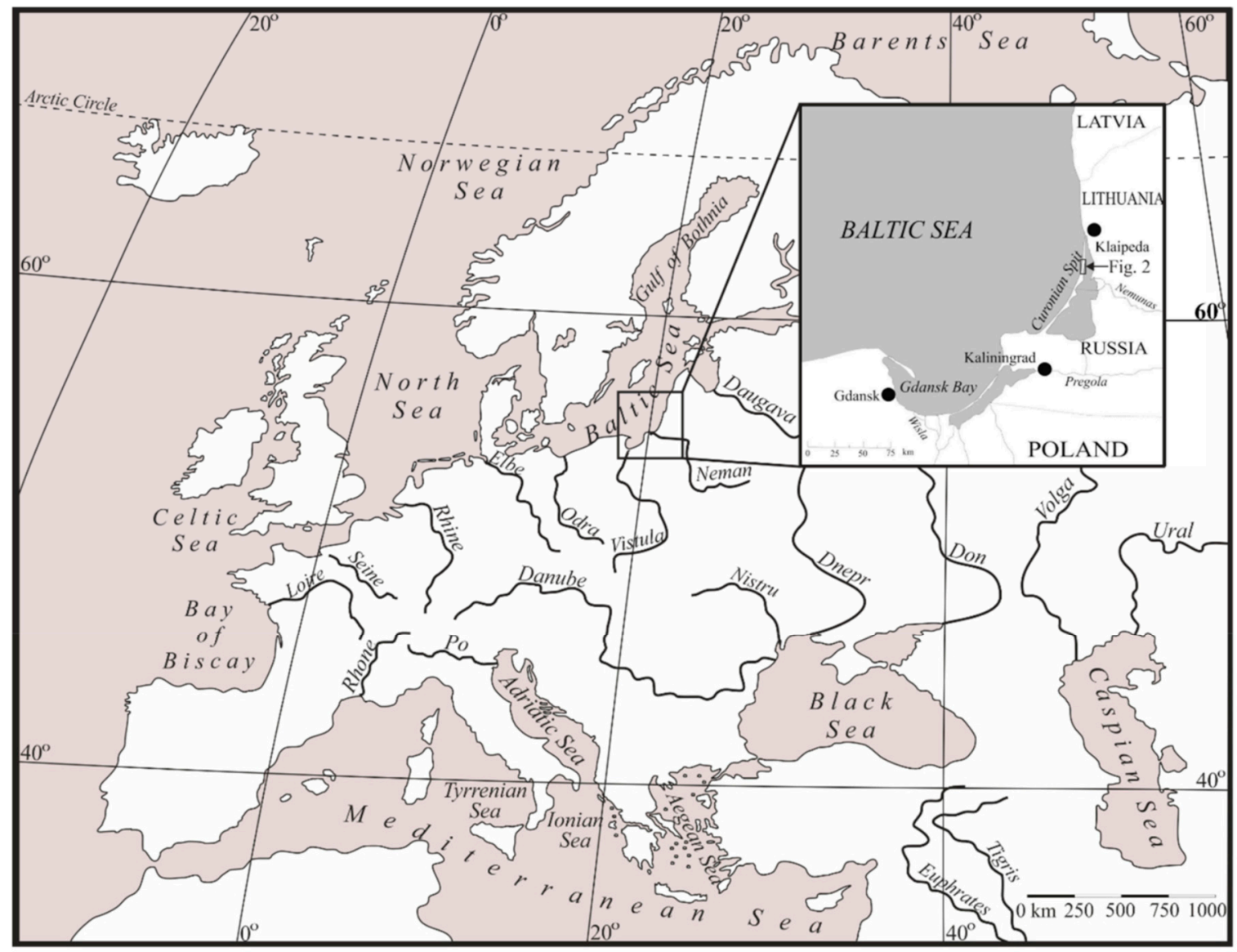

Figure 1. Location of the Curonian Spit on the southeast Baltic Sea coast. (Drawn by Arvydas Urbis).

The landscape of the Curonian Spit is symbolically significant for Lithuanians-for locals and tourists alike [64]. The specific semi-natural landscape with mobile dunes, untouched coastline and period cabins communicates the image archetypal to the Lithuanian 
Baltic coast. At the same time, the Curonian Spit, with its distinct nature and the sense of the tamed wilderness, is a favorite international tourist destination [39]. Due to its unique blend of natural, cultural and symbolic values, the entire Curonian Spit was included in the UNESCO World Heritage List as a transboundary cultural landscape of mobile and forested dunes of outstanding international importance [65].

The Great Curonian Dune Ridge of mobile dunes is also protected as a strict nature reserve within the Kurshskaya Kosa national park on the Russian part of the spit (est. 1987), and Kuršiu nerija national park on the Lithuanian part (est. 1991). We have investigated the whole series of the dune habitats on the Curonian Spit, regarding their comparative aesthetic appeal and scenic quality, including dry sand heaths, mobile bare dunes ('white dunes'), fixed dunes with herbaceous vegetation ('grey dunes'), wet dune slacks, as well as all the transitional ecotones between these habitats and the forested ones.

The forest habitats included in our investigation comprise most natural forest and forest plantation types that are abundant on the Curonian Spit, due to a protracted history of dune afforestation [38]. Natural forests and forest plantations cover $62 \%$ of the total area of the spit. Referring to the results of our previous studies $[17,18]$, the most visually appealing forest habitats for domestic Lithuanian visitors are: (i) mature Scots pine forest plantations with dry sand heaths in the background; (ii) mature Scots pine forest plantations; (iii) young Scots pine plantations with grey dunes in the background; (iv) middle-aged Silver birch stands; and (v) mature Norway spruce forest. The remaining forest habitats possess a much lesser visual appeal.

\subsection{Materials and Data Used}

The three photos for each viewshed were obtained in the following manner. First, a full list of the dune, forest and successive transitional habitats of the Curonian Spit was compiled using a pre-existing national database of NATURA 2000 habitats. The photographer (Arvydas Urbis) then took a series of high resolution $(1536 \times 1024$ pixels $)$ monochromatic photos of each viewshed using a digital camera Nikon N5005 wide zoom with a $28-200 \mathrm{~mm}$ focal length Tamron lens, with a $75^{\circ}$ degree field of view. To eliminate the potential bias of photographic representations showing a limited field of view, the photographer produced photographs presenting a viewshed within an angle of $150^{\circ}$ (double width wide zoom photos).

In the screening phase, a team of experts then unanimously selected the three photographs for each viewshed, taking care to ensure that all possible combinations of the surveyed landscape attributes (stages of succession, the naturalness and heterogeneity of scenery) were indeed represented by the images selected [16]. The selection process resulted in a list of 45 short-range viewsheds of various landscapes and habitats of the Curonian Spit. The remaining short-range viewsheds are so rare that visitors rarely see them during their visits to the spit.

We have conducted a pre-test of the distinguishability of the landscape images using a Chi squared-test and have proven $(p<0.00001)$ that lay visitors of the Curonian Spit successfully distinguish different landscapes and their combinations portrayed in the photographs [16]. Hence, the 135 images representing 45 forest and dune landscapes of the Curonian Spit, and their succession and management stages were used as visual stimuli for the paired-comparison survey. The respondents could see any ten of all possible pairs of the objects $(\mathrm{N} \times(\mathrm{N}-1) / 2=990)$ if $\mathrm{N}=45$ sorted in random order.

The viewsheds were repeated 15 times, with each of the three photos representing each viewshed having equal opportunities to be paired with any of the photos representing the other viewsheds. This yielded a final sample of 14,850 pairs. Each respondent had equal opportunities to receive any of the 14,850 pairs of photographs for the paired choice provided in ten randomly sorted pairs in a flipper album. A single evaluator was asked to assess ten pairs of photographs, considering this number to be the biggest possible for an attentive and dedicated judgment by an individual $[17,18]$, thus preventing the visual and mental evaluator's fatigue. 
We completed the paired comparison survey in July and August 2017. The population in the survey comprised all domestic summer visitors to the Lithuanian part of Curonian Spit, currently amounting to 387,000 , according to the data from the toll-point. The sample $(n=1485)$ included randomly selected adult domestic visitors to the Curonian Spit $(0.38 \%$ of the total visitors' population). The survey resulted in a ranking list of normalized values representing the relative aesthetic appeal values of 45 landscapes and habitats of the Curonian Spit.

\subsection{Study Methods}

Figure 2 presents a flowchart of the overall research undertaken in this whole project. The methodology comprised 17 steps accomplished in three stages: STAGE I (AESTHETIC APPEAL INVESTIGATION): Step 1. Compiling a complete list of dune, forest and transitional successive habitats and landscapes; Step 2. Compiling all available short-range viewshed combinations of the immediate and foreground habitats and landscapes; Step 3. Selecting three photos for each of the short-range viewsheds of the habitats and landscapes; Step 4. Testing the distinctiveness of the photo representations of the dune and forest habitats and landscapes of the Curonian Spit by a pilot group of lay respondents; Step 5. Conducting a full-scale on-site survey of visitor choice with a representative sample of the visitors using the photos as visual stimuli; Step 6. Ranking the short-range viewsheds according to their aesthetic appeal based on the results of the survey.

STAGE II (SCENIC QUALITY INTERPRETATION) was carried out in four steps:

Step 7. Literature analysis on the interpretation of the scenic quality concepts in psychophysical and cognitive terms. Step 8. Semi-structured in-depth interviews and focus groups with local inhabitants. Step 9. Eliciting the key aesthetic appeal concepts by a panel of experts using the Delphi technique. Step 10. Triangulation of the results from the three surveys and interpretation of the elicited aesthetic appeal scores as prevailing scenic quality concepts of the area.

The aesthetic appeal values were computed using the method of paired comparisons for the normalized relative ranking of different landscapes of the Curonian Spit [5,16-19]. We have ranked the photos of the examined landscapes and habitats relative to each other regarding their attractiveness. This was achieved by using a simple ranking technique and involved the computation of the proportion of times each photo was judged by the 1485 interviewees as more attractive than any other photo. The computation results were then transformed to normalized values representing the relative aesthetic appeal values of various landscapes. More technical details are given below in Section 2.3. Materials and data used.

STAGE III (LANDSCAPE EVALUATION AND MANAGEMENT DECISION SUPPORT) is the final stage of the whole research project and comprises seven steps.

2.3.1. Step 11. Creating a Spreadsheet of the Normalized Aesthetic Appeal Values of the Immediate and Foreground Habitat Combinations of Coastal Forests and Dunes

First, we have interpreted all 45 ranked images in terms of their short-range viewshed information. Second, we have adapted the approach from [63-65] for a raster ArcGIS map. We have considered the central $20 \mathrm{~m} \times 20 \mathrm{~m}$ cell as an observer's viewpoint, and the surrounding eight $20 \mathrm{~m} \times 20 \mathrm{~m}$ cells as an immediate viewshed (i.e., the shortest-range viewshed, which is around the observer). Meanwhile, the following sixteen $20 \mathrm{~m} \times 20 \mathrm{~m}$ cells were considered a foreground (i.e., the short-range viewshed next to the observer). The principal scheme of the full short-range viewshed is given in Figure 3. 

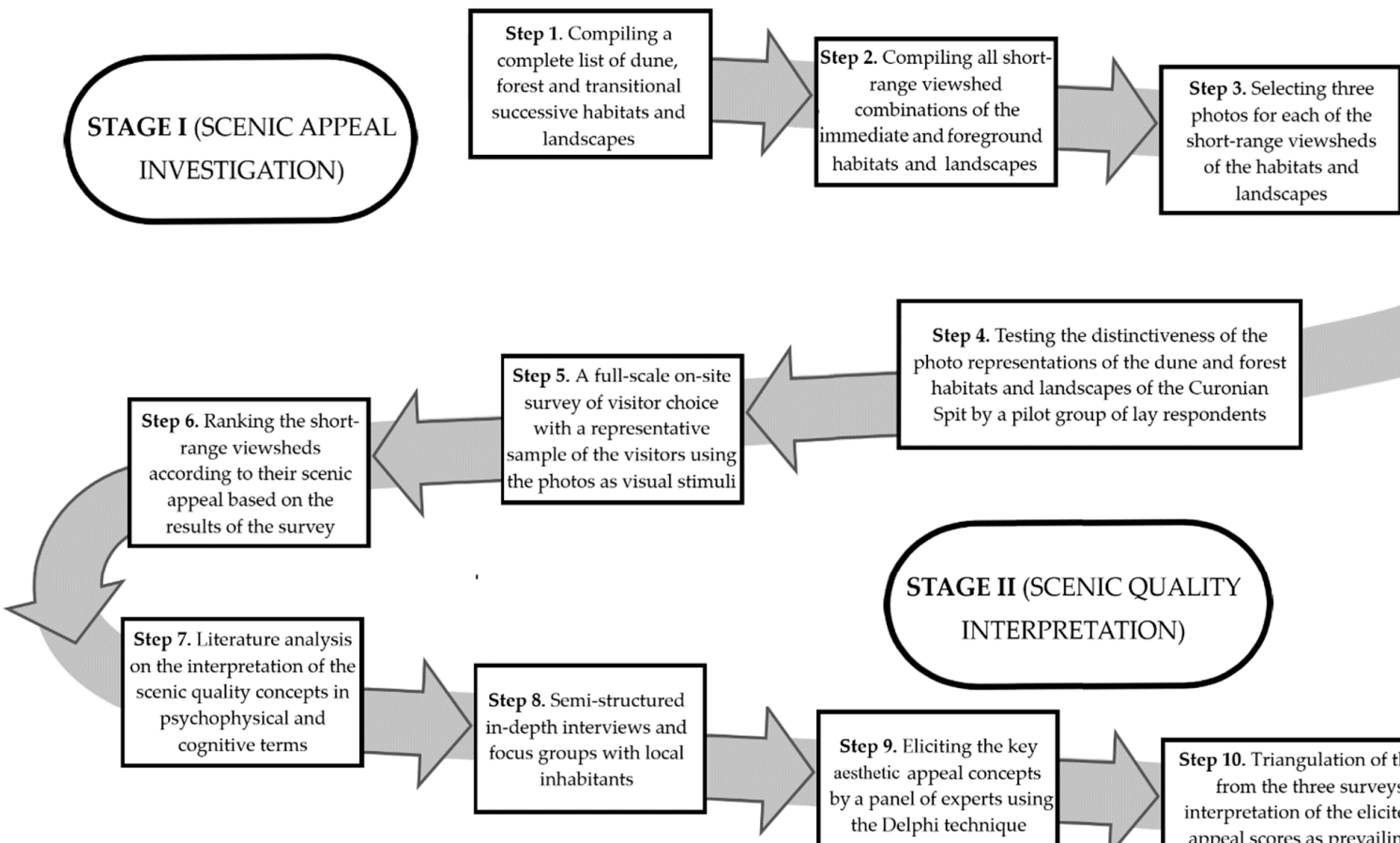

Step 4. Testing the distinctiveness of the photo representations of the dune and forest habitats and landscapes of the Curonian Spit by a pilot group of lay respondents
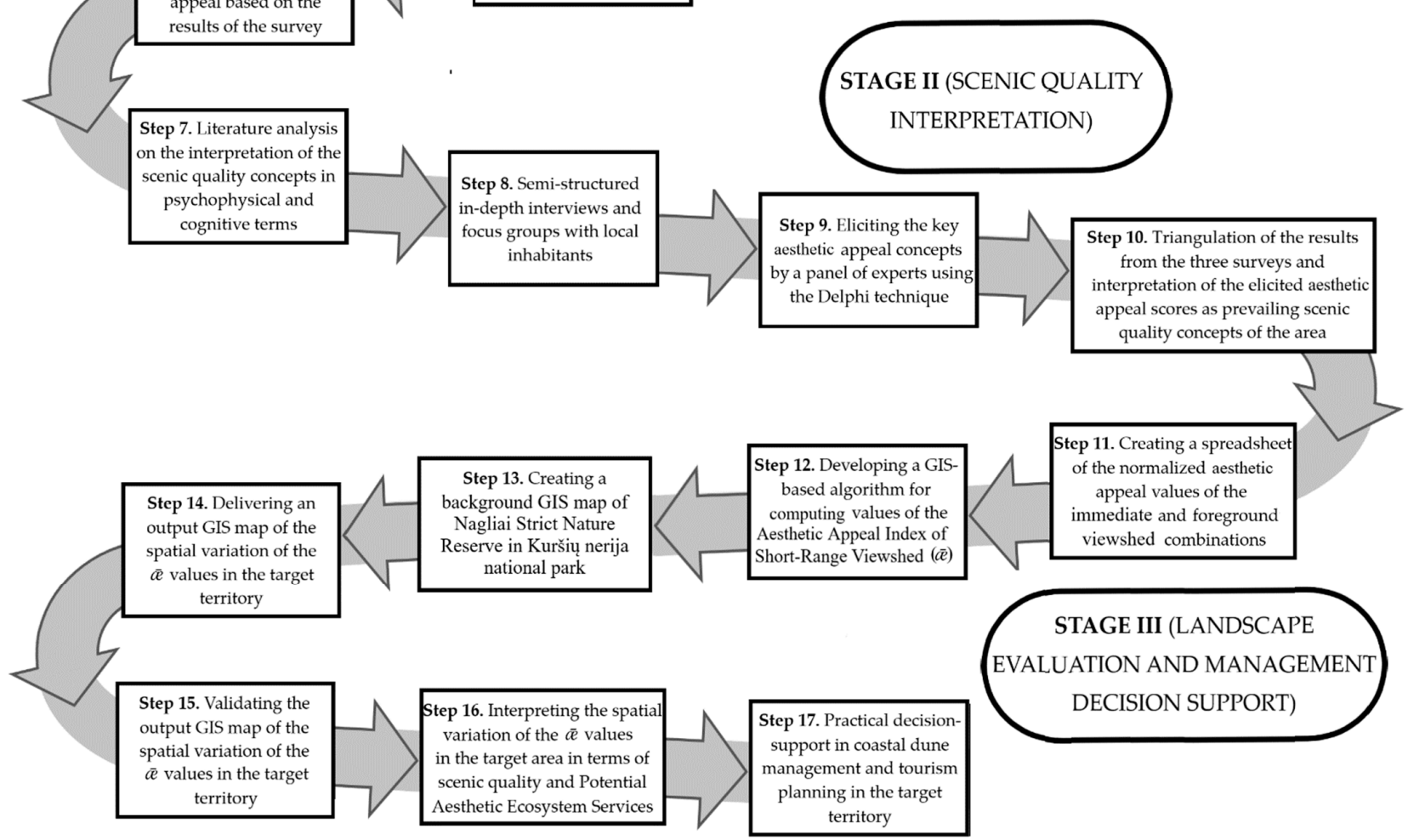

Step 9. Eliciting the key aesthetic appeal concepts the Delphi technique

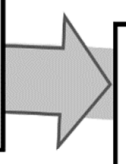

Step 10. Triangulation of the results from the three surveys and interpretation of the elicited aesthetic appeal scores as prevailing scenic quality concepts of the area

Figure 2. The flowchart of stages and steps of the whole research project. (Drawn by Arvydas Urbis).

We then rendered all of the data concerning the aesthetic appeal values of the immediate and foreground habitat combinations of the coastal forests and dunes (normalized from 0 to 1, where 1 is the highest score) into 45 columns and 45 lines of an Excel spreadsheet. The resulting cells of the spreadsheet were segregated into four types (Figure 4):

A. Aesthetic appeal values of the homogeneous habitats stretching over $100 \mathrm{~m} \times 100 \mathrm{~m}$ area deduced directly from the field study results are given in the diagonal cells as the intersections of the same scenery views (Type A cells in Figure 4, 18 cases). The most common habitats include mobile (white) dunes, fixed (grey) dunes and mature Scots pine forest plantations.

B. Aesthetic appeal values of the ecotone habitats, bordering other different habitats at less than $30 \mathrm{~m}$ in any direction from a viewpoint cell when the immediate habitat around the viewpoint cell comprises impermeable thickets obscuring the foreground behind it (Type B cells in Figure 4, 5 cases). In that case we interpret the viewpoint cell as located within a homogeneous habitat, ignoring the foreground of the habitats behind it (Type B cells in Figure 4, five cases). Such cases include mature Mugo pine plantations, young Scots pine plantations, young stands of Silver birch, and Black alder and brushwood of various species. 
C. The aesthetic appeal values of the ecotone habitats, which border other habitats at less than $30 \mathrm{~m}$ in any direction from a viewpoint cell when the immediate habitat around the viewpoint cell provides a permeable viewshed and the combination of the immediate and foreground habitats and landscapes is among the 45 sceneries ranked by the participants in the field survey. In that case, the aesthetic appeal value of a habitat is given in a cell of the spreadsheet where the line represents an immediate habitat and the column represents a foreground habitat (Type C cells in Figure 4, 22 cases). The most common examples include mature Scots pine plantations in the immediate viewshed with white dunes in the foreground, mature Scots pine plantations in the immediate viewshed with dry sand heaths in the foreground, and mature Silver birch stands in the immediate viewshed with mature Norway spruce stands in the foreground.

Finally, the aesthetic appeal values of the ecotone habitats, which border other habitats at less than $30 \mathrm{~m}$ in any direction from a viewpoint cell when the immediate habitat around the viewpoint cell provides a permeable viewshed and the combination of the immediate and foreground habitats and landscapes is not included into the 45 sceneries ranked by the participants in the field survey. In that case, an aesthetic appeal value of a habitat is given in a cell of the spreadsheet where the line represents an immediate habitat and the column represents a foreground habitat. In that case, the aesthetic appeal value of an immediate and foreground habitat combination is calculated using the formula (1) based on the aesthetic appeal value of both homogenous habitats comprising the whole short-range viewshed and taking the visual distance decay effect into account [66-70] (Type D cells in Figure 4, 331 cases):

$$
\mathrm{V}_{\mathrm{n}}=\mathrm{V}_{1}+0.5 \times\left(\mathrm{V}_{2}-\mathrm{V}_{1}\right),
$$

where $V_{n}$ is the resulting aesthetic appeal value of an ecotone habitat, $V_{1}$ is the measured aesthetic appeal value of the immediate habitat, and $V_{2}$ is the measured aesthetic appeal value of a foreground habitat behind the measured immediate habitat.

The most common examples of Type D ecotone habitats include: mature Scots pine plantations in the immediate habitat with semi-mature Black alder stands in the foreground; mature Silver birch stands in the immediate habitat with young Scots pine plantations in the foreground; semi-mature Scots pine plantations in the immediate habitat with mature Mugo pine plantations in the foreground; mobile (white) dunes in the immediate habitat with semi-mature Silver birch stands in the foreground, as well as dry sand heaths in the immediate habitat with young Scots pine plantations in the foreground.

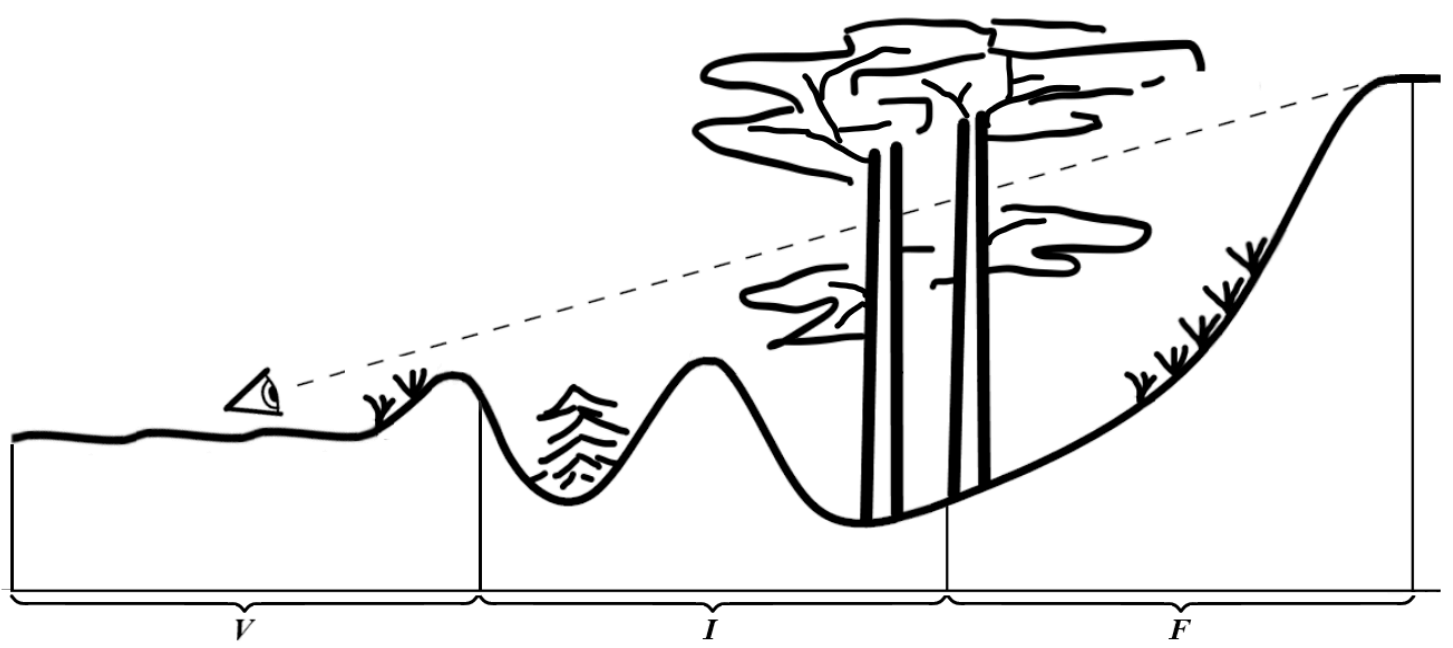

Figure 3. The principal scheme of the short-range viewshed comprising the viewpoint raster cell $(V)$, the immediate viewshed raster cell $(I)$ and the foreground viewshed raster cell $(F)$. (Drawn by Arvydas Urbis). 


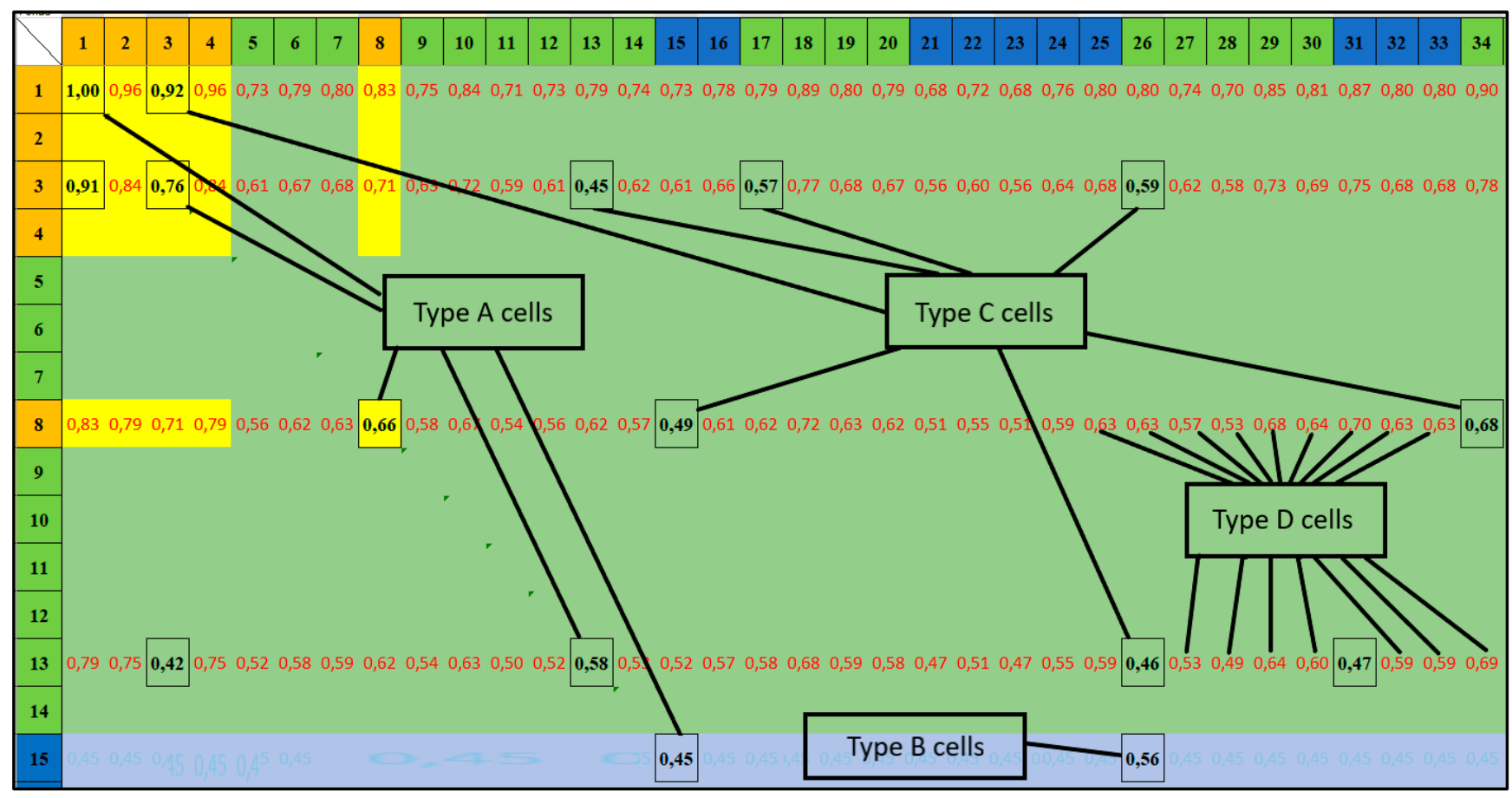

Figure 4. An excerpt from the Excel spreadsheet of the normalized aesthetic appeal values of the immediate and foreground habitat combinations of coastal forests and dunes. (Drawn by Arvydas Urbis).

2.3.2. Step 12. Developing a GIS-Based Algorithm for Computing Values of the Aesthetic Appeal Index for a Short-Range Viewshed $(\bar{x})$

To develop the pilot algorithm for the computation of $\bar{x}$ values, an ArcGIS and Excel interface was used as an extension of a modified GIS-based viewshed analysis technique proposed by Dean and Lizarraga-Blackard [71]. The proposed algorithm is given in Figure 5 and explained below. First, an immediate and a foreground habitat and their types (A, B, C or $\mathrm{D}$ ) have to be identified for each viewpoint in each of the surrounding 24 cells within the $360^{\circ}$ field of view in a GIS-viewshed [70] in 16 directions (Figure 6). If the viewpoint is in a homogeneous habitat stretching over an area of at least one hectare, the $\bar{x}$ value of the viewpoint cell is considered equal to the scenic value for that habitat type quarried from the spreadsheet (Type A or B cells).

If the viewpoint is located in an ecotone habitat, the computing of $\bar{x}$ includes several additional conditions. In the directions where the immediate habitats are visually impermeable, only the scenic value of the immediate habitat, quarried from the spreadsheet (Type B cells), is used for $\bar{x}$ computation. In the directions where the immediate habitats are visually permeable, the scenic values of the foreground habitats are also included in the computation of $\bar{x}$. If this combination falls among the 45 images examined in the field study, we use the deduced values quarried from the spreadsheet (Type C cells); if not, we use the calculated ones (Type D cells).

Finally, for each viewpoint of the ecotone habitats, the $\bar{x}$ value is computed as the average of all deduced values aggregated over $100 \mathrm{~m}$ square grid cells and resulting from the scenic values of the whole short-range viewshed as an average of 16 directions (2):

$\bar{x}_{n}=\left(V_{1 \mathrm{dir}}+V_{2 \mathrm{dir}}+V_{3 \mathrm{dir}}+V_{4 \mathrm{dir}}+V_{5 \mathrm{dir}}+V_{6 \mathrm{dir}}+V_{7 \mathrm{dir}}+V_{8 \mathrm{dir}}+V_{9 \mathrm{dir}}+V_{10 \mathrm{dir}}+V_{11 \mathrm{dir}}+V_{12 \mathrm{dir}}+V_{13 \mathrm{dir}}+V_{14 \mathrm{dir}}+V_{15 \mathrm{dir}}+V_{16 \mathrm{dir}}\right) / 16$

where $\bar{x}_{n}$ is a resulting aesthetic appeal value of $n$ viewpoint of an ecotone habitat, and from $V_{1 \text { dir }}$ to $V_{16 \text { dir }}$ are aesthetic appeal values at each of the 16 directions representing the $360^{\circ}$ field of view of the short-range viewshed and taking into account all cases of the immediate and foreground habitat combinations (Figure 6). 


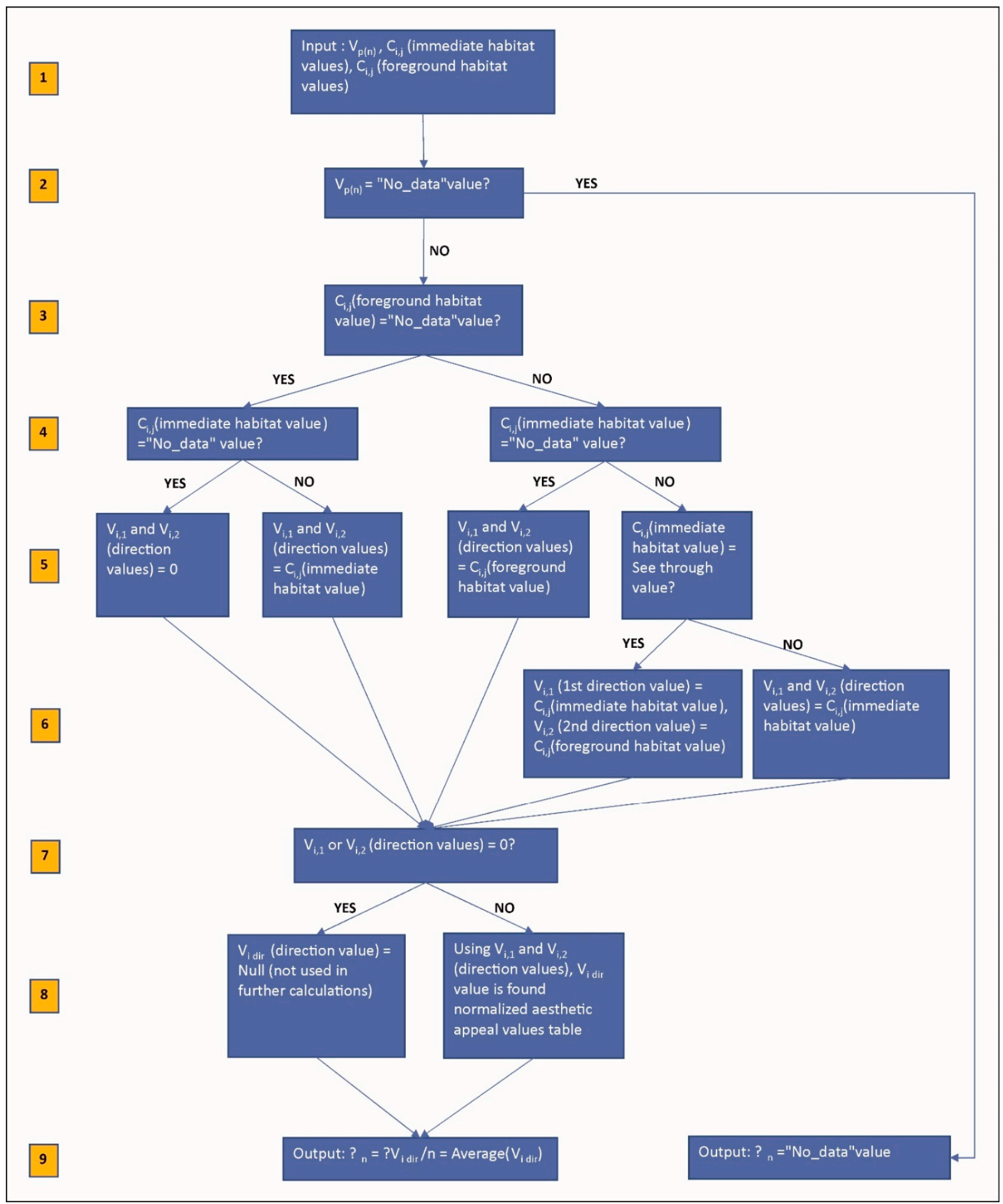

Figure 5. A GIS-based algorithm for computing values of the Aesthetic Appeal Index for a Short-Range Viewshed ( $\bar{x})$. (Drawn by Domantas Urbis). 


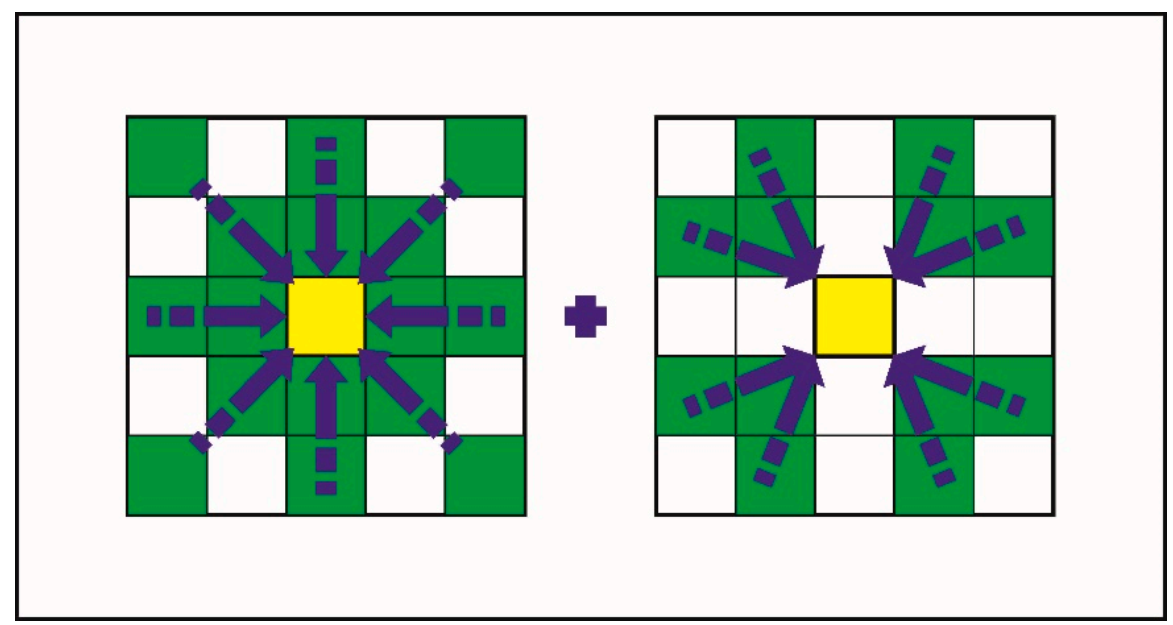

(a)

(b)

Figure 6. The representation of the $360^{\circ}$ field of view by the 16 scenic valuation directions comprising the short-range viewshed; (a) Main (straightforward) scenic valuation directions; (b) Auxiliary (completing) scenic valuation directions. Green cells are those whose habitat features and aesthetic appeal values are accounted for in the sub-process of computation. (Drawn by Arvydas Urbis).

To compute the $\bar{x}$ value at each viewpoint of the ecotone habitats, a dynamic Excel matrix with 25 computational grid cells arranged in 16 directions is applied (Figure 7). The dynamic matrix allows computing of the $\bar{x}$ value in all relevant short-range viewshed cases using the IF function of the Excel program for each grid cell array (3):

$$
V(\text { ndir }=16)=V_{\mathrm{p}(\mathrm{n})} \text { if }\left(\mathrm{C}_{\mathrm{i}, \mathrm{j}}\right) \text {, }
$$

where $V_{\mathrm{p}(\mathrm{n})}$ is the primary scenic value of a habitat, and $\mathrm{C}_{\mathrm{i}, \mathrm{j}}$ is the particular case of an immediate and foreground habitat combination.

\begin{tabular}{|c|c|c|c|c|}
\hline$C_{i-2, j-2}$ & $C_{i-1, j-2}$ & $C_{i, j-2}$ & $C_{i+1, j-2}$ & $C_{i+2, j-2}$ \\
\hline$C_{i-2, j-1}$ & $C_{i-1, j-1}$ & $C_{i, j-1}$ & $C_{i+1, j-1}$ & $C_{i+2, j-1}$ \\
\hline$C_{i-2, j}$ & $C_{i-1, j}$ & $\bar{x}_{n}$ & $C_{i+1, j}$ & $C_{i+2, j}$ \\
\hline$C_{i-2, j+1}$ & $C_{i-1, j+1}$ & $C_{i, j+1}$ & $C_{i+1, j+1}$ & $C_{i+2, j+1}$ \\
\hline$C_{i-2, j+2}$ & $C_{i-1, j+2}$ & $C_{i, j+2}$ & $C_{i+1, j+2}$ & $C_{i+2, j+2}$ \\
\hline
\end{tabular}

Figure 7. The dynamic matrix with 24 computational grid cells rendered in 16 directions for computing of the $\bar{x}$ values at the central viewpoints of the short-range viewsheds of the ecotone habitats. (Drawn by Arvydas Urbis).

2.3.3. Step 13. Creating a Background GIS Map of the Target Territory (Nagliai Strict Nature Reserve and Its Buffer Zone in the Kuršiu Nerija National Park)

To develop a GIS-based algorithm for computing the $\bar{x}$ values, ArcGIS software (Esri, V10.1; Redlands, CA, USA) was applied. For saving the computation capacity and time of the available hardware, the target territory comprised only Nagliai Strict Nature Reserve of the Kuršiu nerija national park and its buffer zone (ca. 395 hectares). The geographical extent of the study area in terms of latitude and longitude is as follows: from $55^{\circ} 24^{\prime} 55.23^{\prime \prime} \mathrm{N}, 21^{\circ} 2^{\prime} 50.65^{\prime \prime} \mathrm{E}$ in the northeast to $55^{\circ} 32^{\prime} 9.46^{\prime \prime} \mathrm{N}, 21^{\circ} 7^{\prime} 45.70^{\prime \prime} \mathrm{E}$ in the southwest.

In the study area, the topography varies from $1.0 \mathrm{~m}$ in dune slacks to $62.0 \mathrm{~m}$ at the highest peaks of the Great Dune Ridge. The average height of the study area is $4.7 \mathrm{~m}$ 
above sea level. The average height of the Great Dune Ridge in the analyzed area is $26.4 \mathrm{~m}$ above sea level. The target territory is the most representative of habitat and landscape diversity since it contains a whole range of dune and forest habitats and their combinations (Figure 8).

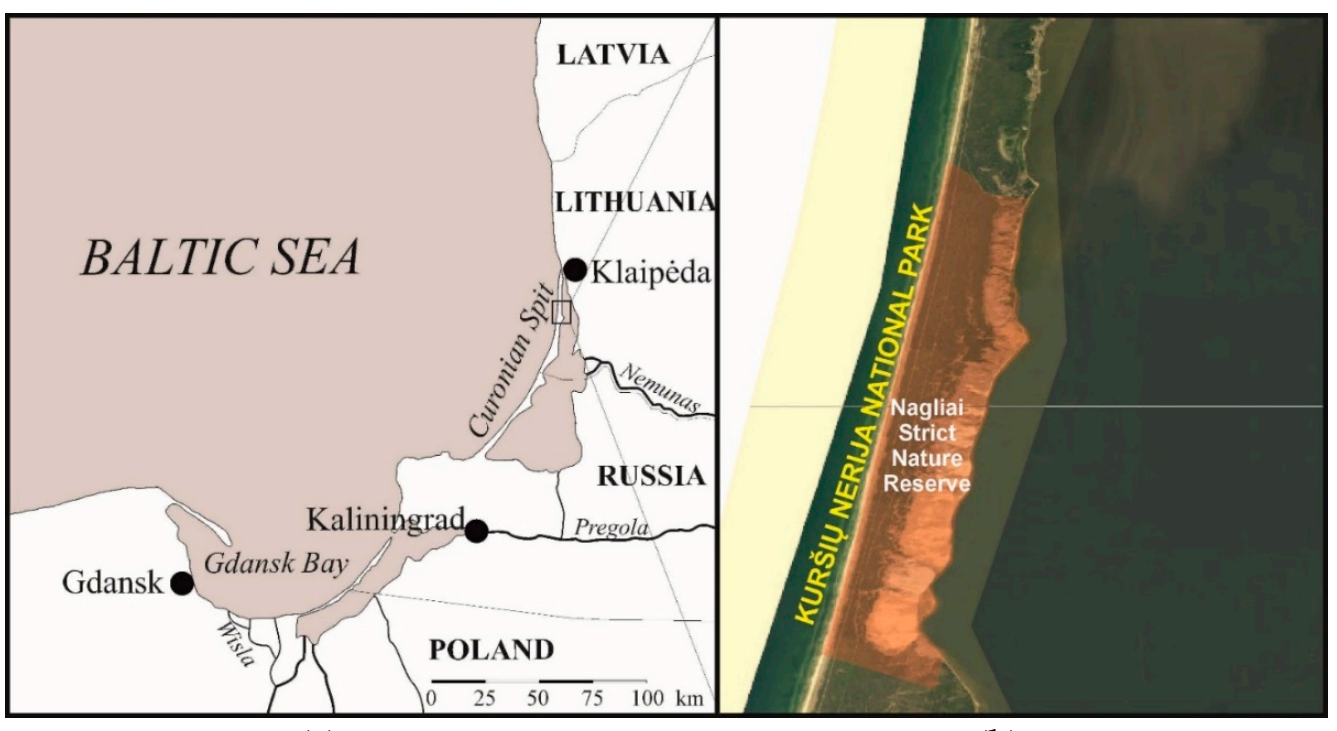

(a)

(b)

Figure 8. The target territory of the GIS background and output maps: (a) The location of the target territory in the Southeast Baltic Area; (b) Nagliai Strict Nature Reserve within the Kuršiu nerija national park. The target area is shadowed in reddish (Drawn by Arvydas Urbis).

We have created the background map of the target territory from the spatial ArcGIS vector database of the State Forest Cadaster of the Republic of Lithuania for each forest plot given in the cadaster. According to the principles of national forest inventory in Lithuania, dunes and dry sand heaths are also included in the forest cadaster. We have exported the vector data of Nagliai Strict Nature Reserve and its buffer zone from the State Forest Cadaster to a raster layer (cell size $20 \mathrm{~m} \times 20 \mathrm{~m}$ ). As mentioned above, each cell of the background map was interpreted in all three functions: as a viewpoint, an immediate habitat of the viewpoint and a foreground habitat of the viewpoint.

2.3.4. Step 14. Delivering an Output GIS Map of the Spatial Variation of the $\bar{x}$ Values in the Target Territory

The output GIS map of the spatial variation of the $\bar{x}$ values in Nagliai Strict Nature Reserve and its buffer zone was produced as an additional ArcGIS raster layer based on the computation of the $\bar{x}$ values for each raster cell of the territory done in Step 13 (Figure 8). This helps to gain an overview of the spatial variation of the $\bar{x}$ values compared to the national park management regime layer, the extent of conservation policy restrictions in this protected coastal dune and forest area, and the location and availability of potential aesthetic ecosystem services (PAES) for tourists across the whole range of dune and forest landscapes. The output map resolution is $20 \mathrm{~m} \times 20 \mathrm{~m}$ of each raster cell as for the background GIS map.

2.3.5. Step 15. Validating the Output GIS Map of the Spatial Variation of the $\bar{x}$ Values in the Target Territory

Suppose the statistical analysis shows a validated and significant correlation between GIS-based modelled aesthetic appraisal values of the short-range viewsheds and the visitors' scenic quality ratings. In that case, we can apply this output for the area-wide simulation of scenic quality using the GIS [72]. Therefore, to validate the output GIS map statistically, independently acquired data from a field study on aesthetic appraisal of short-range viewsheds of coastal dune and forest landscapes were used. The predicted $\bar{x}$ 
values for all the grid cells within the target territory of Nagliai Strict Nature Reserve were correlated with the elicited ones during a specially conducted on-site route survey.

The field data were collected via a questionnaire that was distributed to university students following the methodology proposed by Chhetri and Arrowsmith [73]. Field measurements of aesthetic appraisal of the short-range viewsheds were recorded by a convenience sample of 44 Klaipeda University students hiking along the walking trail or without any track in the open dunes and mature forest plantations (Figure 9). The students collected the field data by completing questionnaires. They had to evaluate the aesthetic appeal of the entire $360^{\circ}$ field of view on a ten-point Likert scale at the 100-stop series of observation points along the track (Figure 10).

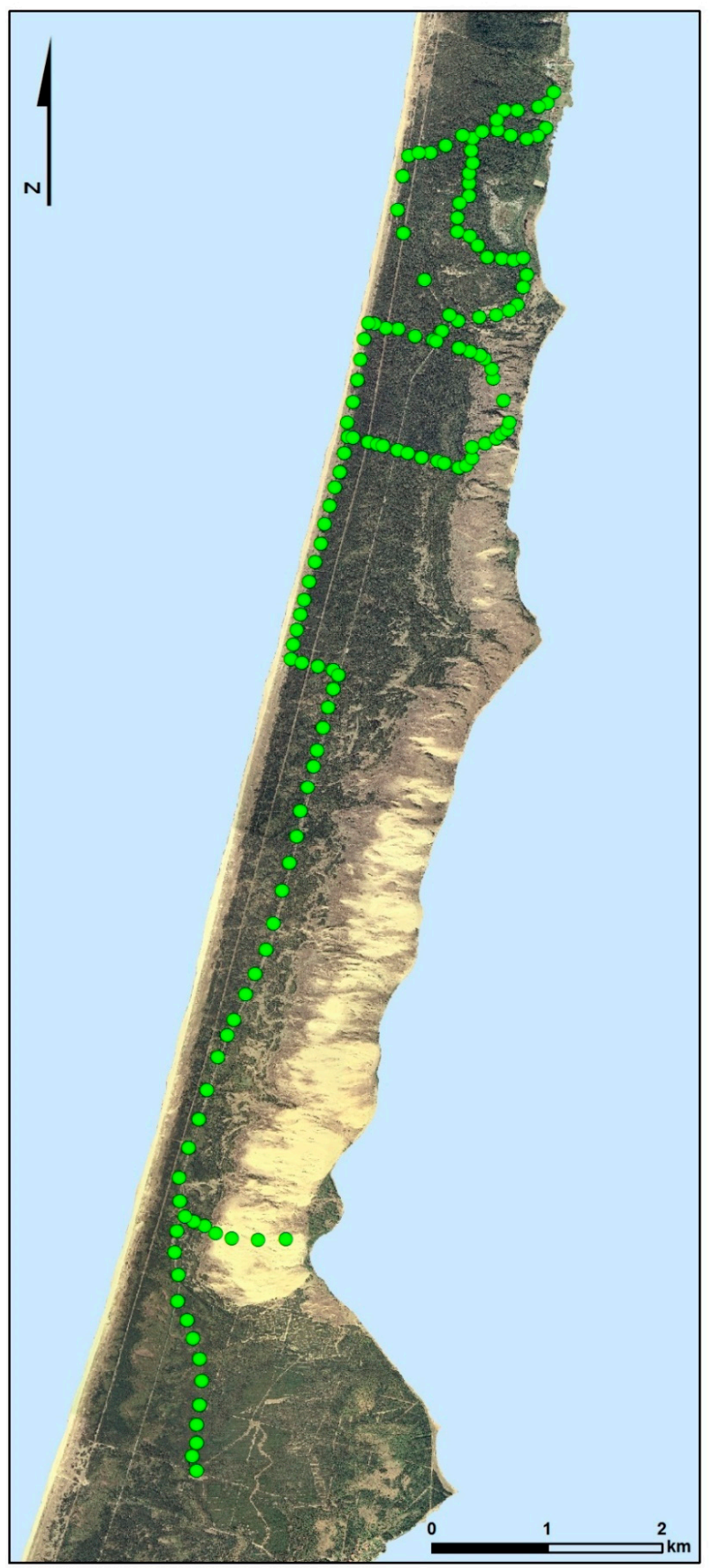

Figure 9. The hiking route in Nagliai Strict Nature Reserve and its buffer zone with the points of the field validation of the simulated aesthetic appeal values. (Drawn by Egidijus Jurkus). 


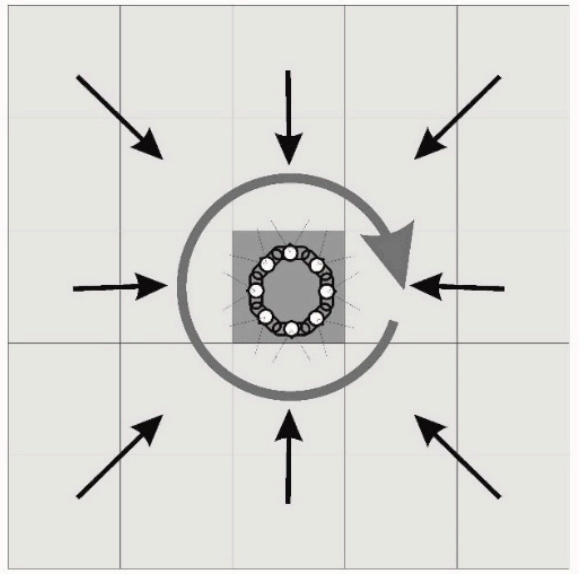

(a)

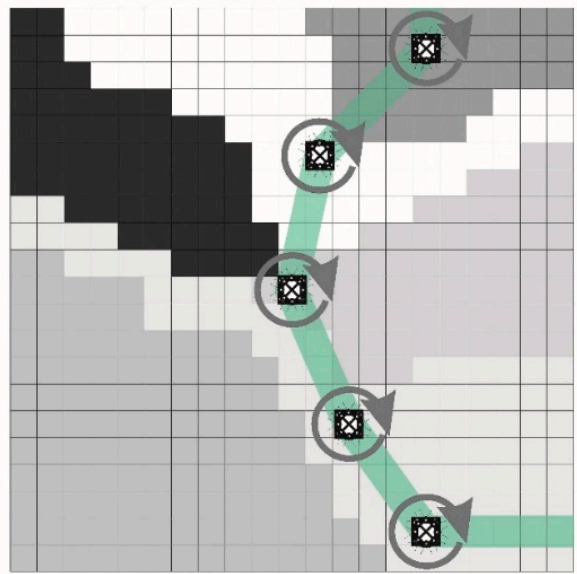

(b)

Figure 10. The principal scheme of validating the output GIS map of the spatial variation of the $\bar{x}$ values in the target territory by a group of observers: (a) The short-range viewshed observation and validation point; (b) The part of the hiking route with the series of the short-range viewshed observation and validation points. (Drawn by Arvydas Urbis).

The students were divided into four groups with 11 persons each. The first group hiked in one direction on the first day in May of 2019 and the second group walked in the reverse direction on the same day. The purpose was to see whether preceding events impacted upon responses given. The third and fourth groups repeated the survey, following the same route and stopping at the same points on the second day, in May of 2019. Both days were sunny with few clouds and air temperature hovering around $16^{\circ}$ to $17^{\circ} \mathrm{C}$, typical weather at the beginning of the tourist season on the Curonian Spit.

The length of the survey trail was $15.9 \mathrm{~km}$ (Figure 9). The stops for the $360^{\circ}$ field of view assessment of the aesthetic appraisal of the short-range viewshed were at each 100 to $200 \mathrm{~m}$ aiming to choose the most representative dune and forest habitats sites. Altogether, there were 100 valid points of the survey. The locations have been identified using the GPS receivers Garmin Oregon 600 with positioning information based on $\mathrm{x}$ and $\mathrm{y}$ orthogonal coordinates in a WGS84 system. The position accuracy was $3 \mathrm{~m}$. In addition, the two professional researchers guiding the groups recorded the biophysical details of the locations in terms of forest succession, age and composition, and landscape features.

Hull and Stewart [74] and Chhetri et al. [34] observe that the mood of an aesthetic appraisal varies throughout a hiking survey. They propose the notion of 'experienced landscape' containing three key elements: (1) encountered landscape, (2) sequence and (3) feelings. Encountered landscape comprises the seen views, the people and the objects in a landscape. A sequence is an order in which these scenes or objects are encountered. Feelings are the subjective emotions felt while encountering these views [34,74]. For validating the GIS-based model of the aesthetic appraisal of short-range viewsheds, at each point, the students were asked to look around and judge the aesthetic appeal of the entire $360^{\circ}$ field of view, answering the question: "How attractive do you find the landscape surrounding you?".

The last step in the validation of the GIS-based model of the aesthetic appraisal of short-range viewsheds was the calculation of the correlation between the predicted aesthetic appeal ratings and the averaged aesthetic appeal ratings actually assessed in the field at each of the 100 hiking event points using a bivariate correlation (Pearson's $r$ ). This is a measure of linear association between the simulated and the actual, independent sets of ratings [75]. The calculation of the Pearson's correlation coefficient was completed by a standard Excel function PEARSON, which calculates the $r$ values for the dataset automatically. 
2.3.6. Step 16. Interpreting the Spatial Variation of the $\bar{x}$ Values in the Target Area in Terms of Scenic Quality and PAES

To interpret the spatial variation of the $\bar{x}$ values in the target area in terms of scenic quality and PAES, a focus group was conducted in August 2021. Quoting a recent study by Gundumogula, who have summarized the main methodological principles of successful conducting of focus groups [76] (p. 301):

'Focus groups help to discover new aspects and information of one's research, as the participants own and contribute together much more and more diverse perspectives on the selected topic than the researcher could imagine alone. Focus groups have a high chance to catch and consider the peoples' feeling, ex-pressions, views, believes and responses while collecting the data.'

The necessary information was obtained from an informal discussion with six practitioners and experts in a focus group comprised of people with first-hand knowledge of the sector, including an economist, a psychologist, a geographer, an environmentalist, and other professionals, in which this small number of experts were asked to informally discuss various aspects of scenic quality distribution in the target territory to include the practitioner's perspective. The aim of the focus group was to establish a conceptual link between the scenic quality and the PAES since the former notion is based on simulated and validated tourist offer-related aspects of the aesthetic appeal of coastal dunes and forests whilst the latter notion is tourist demand-related.

There are differing opinions on the optimal size of the focus groups ranging from four to twelve participants [76]. The moderator facilitated the intercourse within the focus group with a set of lightly structured open-ended questions. These questions, or rather topics, did not restrict the direction taken by each discussion stage. Participants were encouraged to discuss their experiences in applying the aesthetic appeal as an incentive to visit the coastal dunes and forests of the Curonian Spit. To facilitate the free flow and openness of the discussion, the note-keeper took written notes without audio or video recording of the session.

2.3.7. Step 17. Practical Decision-Support in Coastal Dune and Forest Management and Tourism Planning in the Target Territory

In order to determine the most effective landscaping measures by improving the aesthetic appeal of the landscape in the target territory (increasing the scenic value):

1. Areas that are important to visitors for their aesthetic appeal (e.g., near tourist trails) have been identified. For this purpose, the existing or planned trail routes or the existing or planned beauty spots were marked on the forest management plot plans.

2. In the target territory, with the help of the developed methodology, the areas of the lowest aesthetic value were determined. In cases where these areas are extensive, special localized scenic quality improvement measures have been proposed. The primary visual assessment threshold matched the area's clearly defined landscape elements (e.g., dune foot, dune slacks, hummocks or hollows). Furthermore, in selected areas of low aesthetic value, the GIS model helped determine which taxonomic parameters of the habitat or landscape reduce the short-range scenic value and which correction would allow for forming a more aesthetically appealing scenery.

3. Specific landscaping measures (clear-cutting, thinning, planting) were selected in the identified plots. We have assessed how the essential parameters and scenery type may change. On this basis, landscaping measures were selected and implemented. After performing these, the plots were inventoried by determining the changed landscape scenic quality parameters, and the type of the newly formed scenery was specified. Finally, the calculations of new $\bar{x}$ values were performed for various forest and dune plots, and the resulting change in scenic quality value was estimated. 


\section{Results}

\subsection{GIS Output Map of the Short-Range Viewshed Scenic Quality and Its Validation}

As a result of computations using the developed GIS-based algorithm for computing the Aesthetic Appeal Index for a Short-Range Viewshed ( $\bar{x})$, anArcGIS raster layer with a grid resolution of $20 \mathrm{~m} \times 20 \mathrm{~m}$ cells based on the computation of the $\bar{x}$ values for each raster cell was created, showing the spatial variation of the computed $\bar{x}$ values in Nagliai Strict Nature Reserve and its buffer zone of Kuršiu nerija national park and distribution of the zones with low, medium and high scenic quality (Figure 11). This integrates an objective digital map of habitats with subjective scenic preferences of coastal forest and dune landscapes based on psychophysical and cognitive perceptions of scenic beauty and translates these subjective scenic preferences to $\bar{x}$ values.

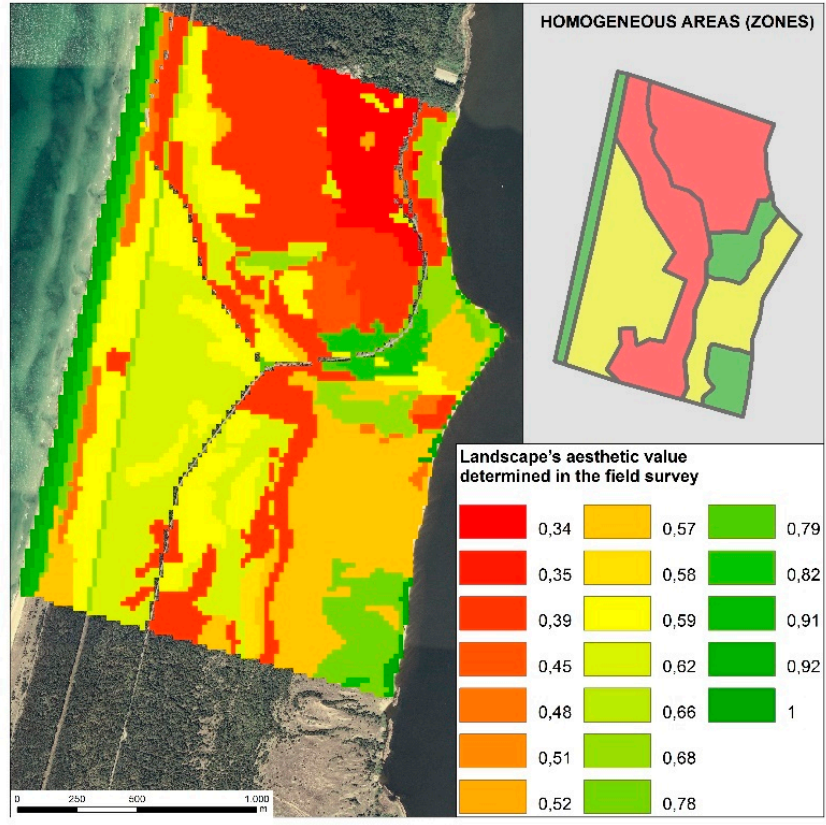

(a)

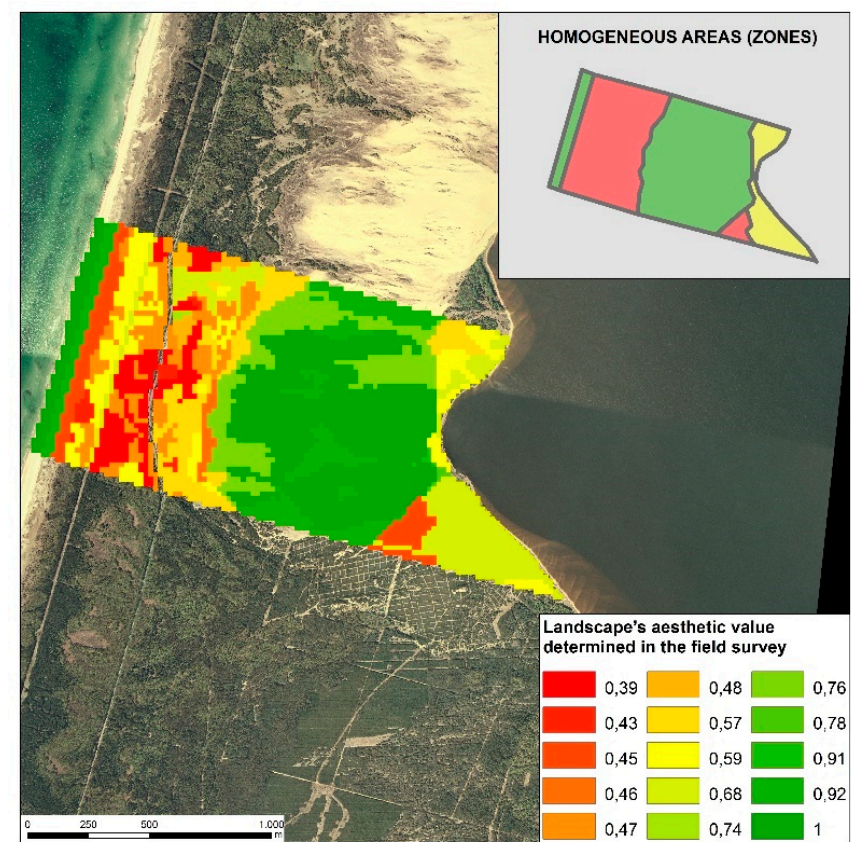

(b)

Figure 11. Zoning of Nagliai Strict Reserve and its buffer zone on the basis of computed values of scenic quality. Homogeneous areas (zones) of low (red), medium (yellow) and high (green) scenic quality are distinguished, between which there are transitional value buffers: (a) Northern part of Nagliai Strict Reserve and its buffer zone; (b) Southern part of Nagliai Strict Reserve and its buffer zone. The mobile (white) dunes of Nagliai Strict Reserve, with restricted access, enjoy the highest values of scenic quality. (Drawn by Arvydas Urbis).

We note a distinct positive Pearson's correlation between the modelled and observed short-range aesthetic appeal values at 100 viewpoints $(r=0.77, p<0.0005)$. This result indicates high validity for a modelled short-range aesthetic appeal values using the created and applied GIS-based computation algorithm (Figure 12). Roth et al. [23] indicate that, from a social sciences and psychology perspective, a value of $r>0.5$ shows a strong effect, whereas from a geographical perspective, a value of $0.6<r<0.8$ shows a distinct effect. For instance, Palmer [68] considers Pearson's $r=0.587$ between the modelled scenic appeal ratings and the ratings made in the field at the 73 viewpoints used for visual simulations as sufficient [68].

\subsection{GIS-Based Decision Support for Scenic Quality Management}

The comparison of GIS data before and after the intervention measures into the dune and forest management, or changes that happened due to natural succession processes allowed us to create another ArcGIS raster layer indicating zones with the resulting scenic value changes of the near-range viewshed and their direction (positive-neutral-negative). 
The obtained results allowed the analysis of the distribution of the scenic value of the landscapes in the territory based on the new ArcGIS raster layer reliably and to evaluate the suitability of the intervention measures that have taken place in terms of scenic quality (Figure 13).

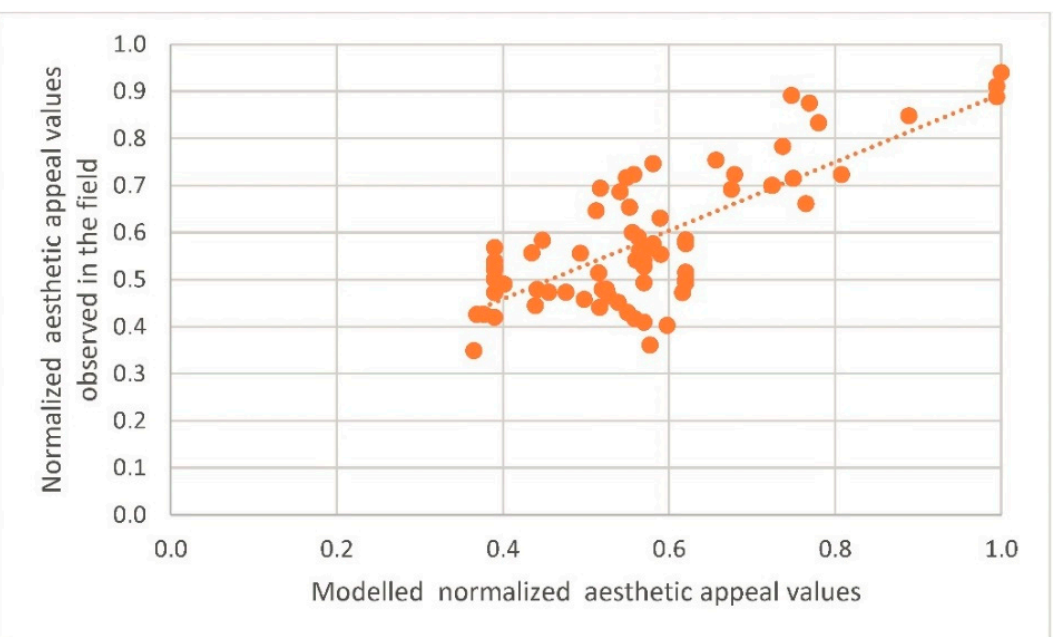

Figure 12. Pearson's correlation between the modelled and observed short-range aesthetic appeal values at 100 viewpoints $(r=0.77, p<0.0005)$. (Computed and drawn by Arvydas Urbis).

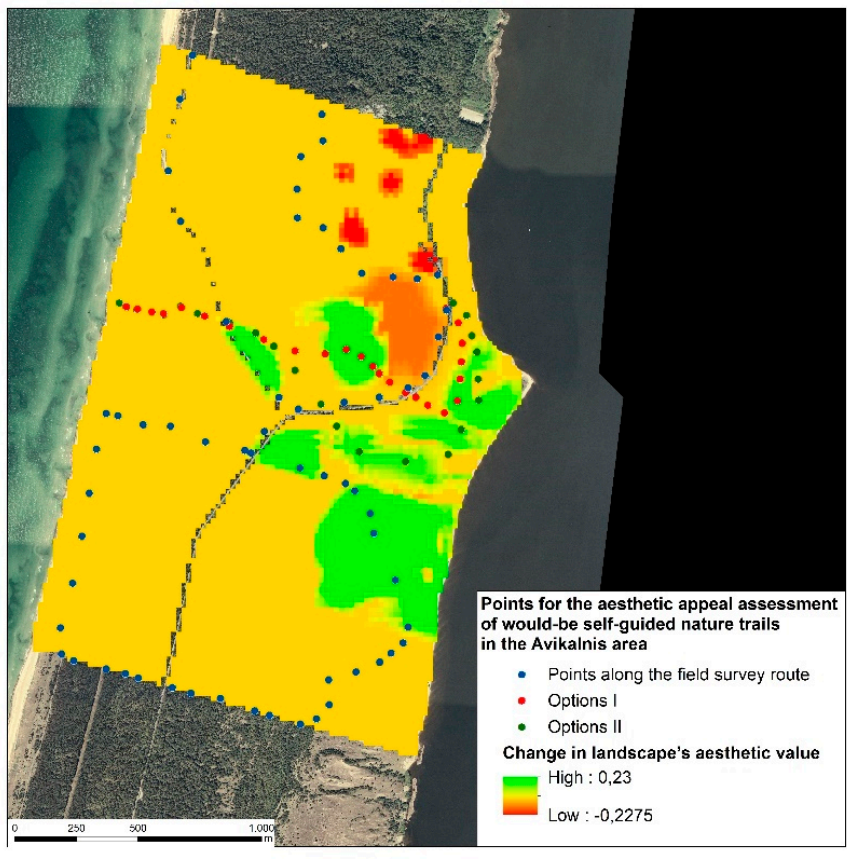

(a)

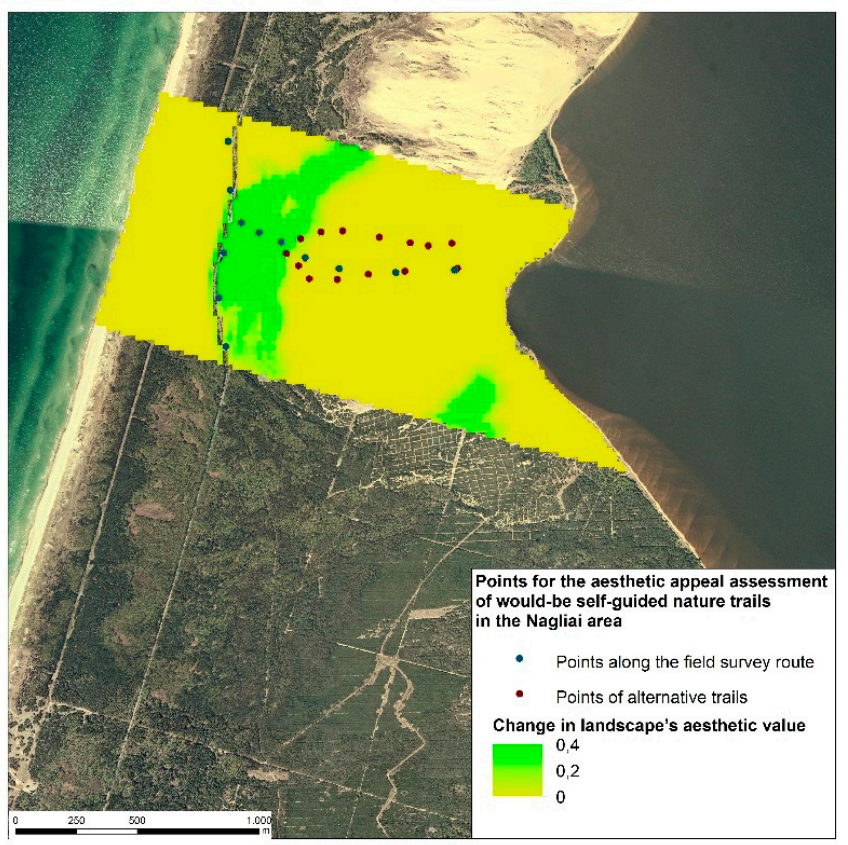

(b)

Figure 13. ArcGIS layer of the zones with scenic quality changes resulting from intervention measures or natural succession from 2010 to 2020: (a) Northern part of Nagliai Strict Reserve and its buffer zone; (b) Southern part of Nagliai Strict Reserve and its buffer zone. Yellow—no scenic value change; red-negative changes; green-positive changes field survey points marked as black dots. Note the decline of scenic quality in the buffer zone of the northern part of Nagliai Strict Reserve due to the overgrowth of grey dunes resulting from the natural succession. (Drawn by Arvydas Urbis).

As mentioned, in the Nagliai Strict Nature Reserve, with the help of the developed methodology, the areas of low aesthetic value were determined. In cases where these areas are extensive, special localized scenic quality improvement measures have been proposed. The primary visual assessment threshold matched the area's clearly defined 
landscape elements (e.g., dune foot, dune slacks, hummocks or hollows). Furthermore, in selected areas of low aesthetic value, the GIS model helped to determine which taxonomic parameters of the habitat reduced the short-range scenic value, and correction measures were proposed to form a more aesthetically appealing scenery.

Last but not least, based on the research results, the methodology for planning, selecting and optimizing linear landscape elements was created and successfully tested. The scenic quality of the surrounding landscape of a self-guided nature trail in Nagliai Strict Nature Reserve (providing the only access for the visitors to the strict nature reserve) was assessed for three planned alternatives. Based on the results of computing the scenic quality, the route with the highest aesthetic value was proposed and successfully implemented as a pilot project (Figure 14). It enabled balancing the psychophysical and cognitive aspects of the aesthetic appraisal of coastal dunes and forests with the conservation prescriptions of Kuršiu nerija national park [39].

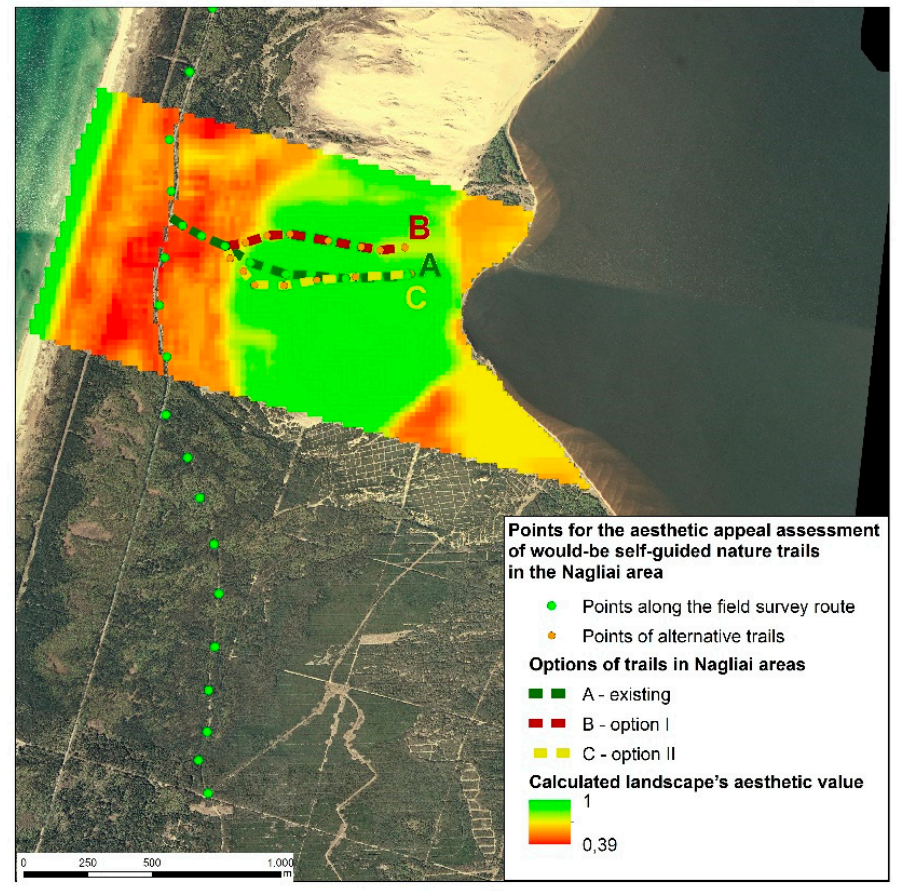

(a)

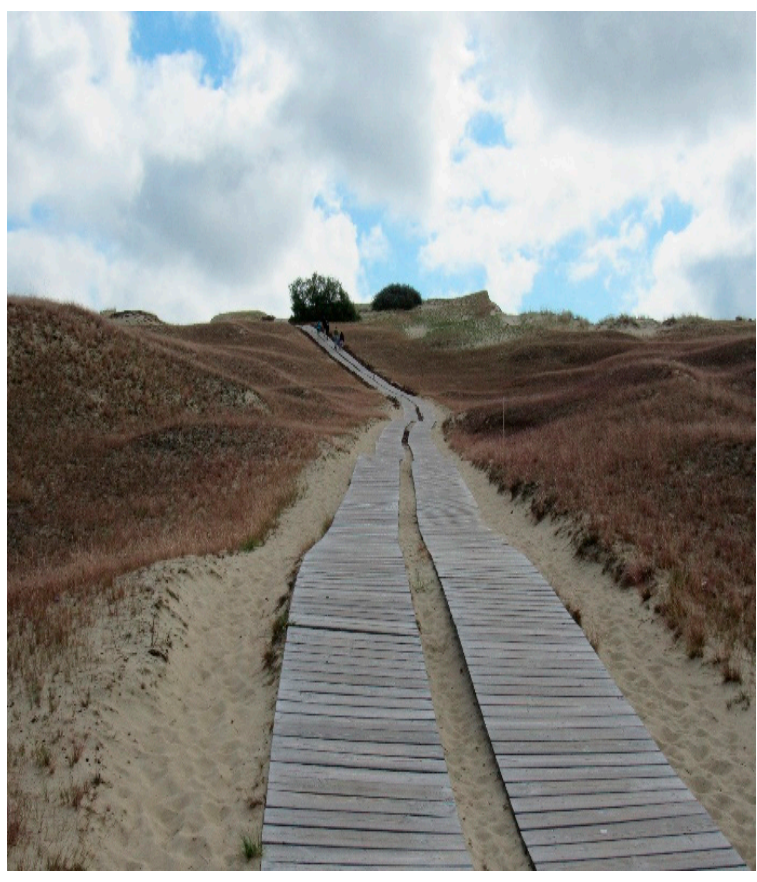

(b)

Figure 14. The scenic quality of the surrounding landscape of a self-guided nature trail in Nagliai Strict Nature Reserve.: (a) Three planned alternatives and the scenic quality of their surrounding landscape; (b) The self-guided nature trail in Nagliai Strict Nature Reserve (providing the only access for the visitors to the strict nature reserve). (Map and photo by Arvydas Urbis).

\section{Discussion}

The focus group helped to identify aesthetic criteria and attributes as one of the main reasons for choosing the Curonian Spit as a tourist destination at the seaside. Furthermore, it exposed why specific attributes were more important for tourists' satisfaction levels. As observed by Pérez-Hernández et al. [77], the scenic quality of mobile dunes with a natural and open background is usually much higher than that of any forested landscape. The aesthetic demand concepts were elicited through a focus group in which six practitioners with 20+ years of experience in tourism-related services and a background in marketing, psychology, landscape management, nature conservation, entertainment industry and geography were asked to informally discuss their involvement with dune aesthetics, their scenic preferences, and their connection to nature tourism.

As mentioned above, the interpretation of the spatial variation of $\bar{x}$ values in the target area focused on establishing a conceptual link between the scenic quality and the 
PAES since the former notion relies on tourist offer-driven aspects of the aesthetic appeal of coastal dunes and forests whilst the latter notion is demand-driven. Participants discussed their experiences in applying the aesthetic appeal as an incentive to enjoy the coastal dunes and forests of the Curonian Spit. It became clear that, for some participants, the Curonian Spit meant primarily travelling to the mobile dune areas and nothing more, whereas for others, dune tourism follows naturally from enjoying the 'peace and quiet' of the Curonian Spit as part of their lifestyle.

Eight relishing aspects [78] have been elicited as the source of PAES of the dune and forest landscapes of the Curonian Spit from the focus group discussions (without rating any priority): (1) staginess; (2) visuality; (3) affectedness; (4) liminality; (5) apprehensiveness; (6) sense of togetherness; (7) uniqueness; and (8) knowledgeability. The focus group concurred that the perceived scenic quality leads to perceived PAES, which leads to visit intentions $[79,80]$. The concept of the image of the Curonian Spit as a visually unique destination did emerge in the focus group discussions. Still, the term brand did not. All focus group participants believed that the Curonian Spit image was an essential issue, including those who did not have any business or research interests there.

\section{Conclusions}

The most significant finding of our research was discovering the role of the double short-range viewshed in comprising the immediate viewshed and the foreground viewshed for the psychophysical investigations in landscape aesthetics. This discovery resulted in the practical development of an innovative GIS-based aesthetic appraisal methodology for coastal dunes and forests with high recreational and conservation value. Therefore, we may conclude that the combined aesthetic appraisal of the short-range viewshed, comprising the immediate and foreground viewshed of coastal forests and dunes, applying a specially created GIS algorithm, allows for assessing the scenic quality of this landscape reliably (Pearson's $r=0.77, p<0.0005$ ).

Relying on the results of our comprehensive research project on GIS-based aesthetic appraisal of the short-range viewsheds of coastal dune and forest landscapes, we created a decision-support system for the coastal dune and forest management in Kuršiu nerija national park. This system converted the objective forest and dune habitat data into the scenic quality and PAES values. Therefore, the recommendations for further work focus on two interrelated avenues of research: (1) to investigate the role of the near background in aesthetic appraisal of short-range viewsheds; and (2) to incorporate the aesthetic valuation of water bodies in the foreground and background into the developed GIS-based algorithm of aesthetic appraisal of short-range watersheds.

Author Contributions: Conceptualization, A.U., J.T. and R.P.; methodology, A.U., E.J. and R.P.; software, A.U., E.J. and D.U.; validation, A.U. and R.P.; formal analysis, A.U., E.J. and R.P.; investigation, A.U., J.T. and R.P.; resources, A.U.; data curation, A.U., E.J. and D.U.; writing—original draft preparation, A.U. and R.P.; writing—review and editing, A.U. and D.U.; visualization, A.U., E.J. and D.U.; supervision, J.T. and R.P.; project administration, A.U. All authors have read and agreed to the published version of the manuscript.

Funding: Lithuanian Research Council funded this research, grant number NKPDOKT15019.

Informed Consent Statement: Informed consent was obtained from all subjects involved in the study.

Data Availability Statement: All data supporting reported results can be found on the server of Klaipeda University.

Conflicts of Interest: The authors declare no conflict of interest.

\section{References}

1. Zube, E.H. Perceived land use patterns and landscape values. Landsc. Ecol. 1987, 1, 37-45. [CrossRef]

2. Vining, J.; Stevens, J.J. The assessment of landscape quality: Major methodological considerations. In Foundations for Visual Project Analysis; Smardon, R.C., Palmer, J.F., Felleman, J.P., Eds.; John Wiley: New York, NY, USA, 1986; pp. 167-186. 
3. Daniel, T.C. Whither scenic beauty? Visual landscape quality assessment in the 21st century. Landsc. Urban Plan. 2001, 54, 267-281. [CrossRef]

4. Bergstrom, J.C. The Role and Value of Natural Capital in Regional Landscapes. J. Agric. Appl. Econ. 2001, 33, 283-296. [CrossRef]

5. De la Fuente de Val, G.; Atauri, J.A.; de Lucio, J.V. Relationship between landscape visual attributes and spatial pattern indices: A test study in Mediterranean-climate landscapes. Landsc. Urban Plan. 2006, 77, 393-407. [CrossRef]

6. Krause, C.L. Our visual landscape: Managing the landscape under special consideration of visual aspects. Landsc. Urban Plan. 2001, 54, 239-254. [CrossRef]

7. Scott, A. Assessing Public Perception of Landscape: The LANDMAP experience. Landsc. Res. 2002, 27, 271-295. [CrossRef]

8. Booth, P.N.; Law, S.A.; Ma, J.; Buonagurio, J.; Boyd, J.; Turnley, J. Modeling aesthetics to support an ecosystem services approach for natural resource management decision making. Integr. Environ. Assess. Manag. 2017, 13, 926-938. [CrossRef]

9. Schirpke, U.; Timmermann, F.; Tappeiner, U.; Tasser, E. Cultural ecosystem services of mountain regions: Modelling the aesthetic value. Ecol. Indic. 2016, 69, 78-90. [CrossRef]

10. Bubalo, M.; van Zanten, B.T.; Verburg, P.H. Crowdsourcing geo-information on landscape perceptions and preferences: A review. Landsc. Urban Plan. 2019, 184, 101-111. [CrossRef]

11. Goldberg, L. Toward conservation of visual resources at the regional scale. Environ. Pract. 2019, 21, 201-215. [CrossRef]

12. Mederly, P.; Černecký, J. (Eds.) A Catalogue of Ecosystem Services in Slovakia: Benefits to Society; Springer Nature: Cham, Switzerland, 2020; 248p.

13. Raumer, H.G.S.V.; Borsdorff, M.; Roser, F.; Roth, M.; Hildebrandt, S. Recreational Quality and Importance of Landscape: An Approach Beyond Scenic Aspects. J. Digit. Landsc. Archit. 2019, 4, 57-65.

14. Gosal, A.S.; Ziv, G. Landscape aesthetics: Spatial modelling and mapping using social media images and machine learning. Ecol. Indic. 2020, 117, 106638. [CrossRef]

15. Kalinauskas, M.; Mikša, K.; Inácio, M.; Gomes, E.; Pereira, P. Mapping and assessment of landscape aesthetic quality in Lithuania. J. Environ. Manag. 2021, 286, 112239. [CrossRef] [PubMed]

16. Povilanskas, R.; Baziukè, D.; Dučinskas, K.; Urbis, A. Can visitors visually distinguish successive coastal landscapes? A case study from the Curonian Spit (Lithuania). Ocean Coast. Manag. 2016, 119, 109-118. [CrossRef]

17. Urbis, A.; Povilanskas, R.; Newton, A. Valuation of aesthetic ecosystem services of protected coastal dunes and forests. Ocean Coast. Manag. 2019, 179, 104832. [CrossRef]

18. Urbis, A.; Povilanskas, R.; Šimanauskienè, R.; Taminskas, J. Key aesthetic appeal concepts of coastal dunes and forests on the example of the Curonian Spit (Lithuania). Water 2019, 11, 1193. [CrossRef]

19. Lothian, A. Landscape and the philosophy of aesthetics: Is landscape quality inherent in the landscape or in the eye of the beholder? Landsc. Urban Plan. 1999, 44, 177-198. [CrossRef]

20. Zube, E.H.; Sell, J.L.; Taylor, J.G. Landscape perception—Research, application and theory. Landsc. Plan. 1982, 9, 1-33. [CrossRef]

21. Jacobsen, J.K.S. Use of Landscape Perception Methods in Tourism Studies: A Review of Photo-Based Research Approaches. Tour. Geogr. 2007, 9, 234-253. [CrossRef]

22. Rolloff, D.B. Scenic Quality at Crater Lake National Park: Visitor Perceptions of Natural and Human Influence. Ph.D. Thesis, Oregon State University, Corvallis, OR, USA, 1998.

23. Roth, M.; Hildebrandt, S.; Walz, U.; Wende, W. Large-Area Empirically Based Visual Landscape Quality Assessment for Spatial Planning-A Validation Approach by Method Triangulation. Sustainability 2021, 13, 1891. [CrossRef]

24. Brown, T.C. Modeling Forest Scenic Beauty: Concepts and Application to Ponderosa Pine; Rocky Mountain Forest and Range Experiment Station, US Department of Agriculture, Forest Service: Fort Collins, CO, USA, 1984; Volume 256.

25. Brown, T.C.; Daniel, T.C. Predicting scenic beauty of timber stands. For. Sci. 1986, 32, 471-487.

26. Daniel, T.C.; Vining, J. Methodological issues in the assessment of landscape quality. In Behavior and the Natural Environment; Altman, I., Wohwill, J., Eds.; Plenum Press: New York, NY, USA, 1983; pp. 39-83.

27. Ribe, R.G. Is Scenic Beauty a Proxy for Acceptable Management? The Influence of Environmental Attitudes on Landscape Perceptions. Environ. Behav. 2002, 34, 757-780. [CrossRef]

28. Gorbunov, R.V.; Tabunshchik, V.A.; Gorbunova, T.Y. Unresolved theoretical and methodological issues in aesthetic assessment of landscapes. Geogr. Bull. 2020, 3, 6-22. (In Russian)

29. Hansen, A.S. Understanding recreational landscapes-A review and discussion. Landsc. Res. 2021, 46, 128-141. [CrossRef]

30. Karjalainen, E.; Tyrväinen, L. Visualization in forest landscape preference research: A Finnish perspective. Landsc. Urban Plan. 2002, 59, 13-28. [CrossRef]

31. Kaur, E.; Palang, H.; Sooväli, H. Landscapes in change-Opposing attitudes in Saaremaa, Estonia. Landsc. Urban Plan. 2004, 67, 109-120. [CrossRef]

32. Wherrett, J.R. Creating Landscape Preference Models Using Internet Survey Techniques. Landsc. Res. 2000, 25, 79-96. [CrossRef]

33. Cohen, E. The sociology of tourism: Approaches, issues, and findings. Annu. Rev. Sociol. 1984, 10, 373-392. [CrossRef]

34. Chhetri, P.; Arrowsmith, C.; Jackson, M. Determining hiking experiences in nature-based tourist destinations. Tour. Manag. 2004, 25, 31-43. [CrossRef]

35. Buhyoff, G.J.; Wellman, D.J.; Koch, N.E.; Gauthier, L.; Hultman, S.G. Landscape preference metrics: An international comparison. J. Environ. Manag. 1983, 16, 181-190. 
36. De La Fuente De Val, G.; Mühlhauser, S.H. Visual quality: An examination of a South American Mediterranean landscape, Andean foothills east of Santiago (Chile). Urban For. Urban Green. 2014, 13, 261-271. [CrossRef]

37. Sevenant, M.; Antrop, M. Cognitive attributes and aesthetic preferences in assessment and differentiation of landscapes. J. Environ. Manag. 2009, 90, 2889-2899. [CrossRef] [PubMed]

38. Povilanskas, R. Landscape Management on the Curonian Spit: A Cross-Border Perspective; EUCC Publishers: Klaipeda, Lithuania, 2004; 242p.

39. Povilanskas, R.; Armaitienè, A.; Dyack, B.; Jurkus, E. Islands of prescription and islands of negotiation. J. Dest. Mark. Manag. 2016, 5, 260-274. [CrossRef]

40. Zajonc, R.B. On the primacy of affect. Am. Psychol. 1984, 39, 117-123. [CrossRef]

41. Serrano Giné, D.; Pérez Albert, M.J.; Palacio Buendía, A.V. Aesthetic assessment of the landscape using psychophysical and psychological models: Comparative analysis in a protected natural area. Landsc. Urban Plan. 2021, 214, 104197. [CrossRef]

42. Kellert, S.R. Nature by Design: The Practice of Biophilic Design; Yale University Press: New Haven, CT, USA; London, UK, 2018; 214p.

43. Salingaros, N.A. The Biophilic Index Predicts Healing Effects of the Built Environment. J. Biourban. 2019, 8, 13-34.

44. Taylor, R.P. The Potential of Biophilic Fractal Designs to Promote Health and Performance: A Review of Experiments and Applications. Sustainability 2021, 13, 823. [CrossRef]

45. Steinitz, E.S.C. Landscape visibility computation: Necessary, but not sufficient. Environ. Plan. B Plan. Des. 2003, 30, 757-766.

46. Bishop, I.; Hulse, D. Prediction of scenic beauty using mapped data and geographic information systems. Landsc. Urban Plan. 1994, 30, 59-70. [CrossRef]

47. Lange, E.; Hehl-Lange, S.; Brewer, M.J. Scenario-visualization for the assessment of perceived green space qualities at the urban-rural fringe. J. Environ. Manag. 2008, 89, 245-256. [CrossRef]

48. Wissen, U.; Schroth, O.; Lange, E.; Schmid, W.A. Approaches to integrating indicators into 3D landscape visualizations and their benefits for participative planning situations. J. Environ. Manag. 2008, 89, 184-196. [CrossRef]

49. Wu, Y.; Bishop, I.; Hossain, H.; Sposito, V. Using GIS in Landscape Visual Quality Assessment. Appl. GIS 2006, 2, 18.1-18.20. [CrossRef]

50. Xu, H.; Plieninger, T.; Primdahl, J. A Systematic Comparison of Cultural and Ecological Landscape Corridors in Europe. Land 2019, 8, 41. [CrossRef]

51. Baerenklau, K.A.; González-Cabán, A.; Paez, C.; Chavez, E. Spatial allocation of forest recreation value. J. For. Econ. 2010, 16, 113-126. [CrossRef]

52. Grêt-Regamey, A.; Bebi, P.; Bishop, I.D.; Schmid, W.A. Linking GIS-based models to value ecosystem services in an Alpine region. J. Environ. Manag. 2008, 89, 197-208. [CrossRef]

53. Pierskalla, C.D.; Deng, J.; Siniscalchi, J.M. Examining the product and process of scenic beauty evaluations using moment-tomoment data and GIS: The case of Savannah, GA. Urban For. Urban Green. 2016, 19, 212-222. [CrossRef]

54. Aladwan, Z.; Ahamad, M.S.S. Hedonic Pricing Model for Real Property Valuation via GIS-A review. Civ. Environ. Eng. Rep. 2019, 29, 34-37. [CrossRef]

55. Ambrey, C.L.; Fleming, C.M. Valuing scenic amenity using life satisfaction data. Ecol. Econom. 2011, 72, 106-115. [CrossRef]

56. Nicholls, S.; Crompton, J.L. The contribution of scenic views of, and proximity to, lakes and reservoirs to property values. Lakes Reserv. Res. Manag. 2018, 23, 63-78. [CrossRef]

57. Noor, N.M.; Asmawi, M.Z.; Abdullah, A. Sustainable Urban Regeneration: GIS and Hedonic Pricing Method in determining the value of green space in housing area. Procedia-Soc. Behav. Sci. 2015, 170, 669-679. [CrossRef]

58. Poudyal, N.C.; Hodges, D.G.; Fenderson, J.; Tarkington, W. Realizing the economic value of a forested landscape in a viewshed. South. J. Appl. For. 2010, 34, 72-78. [CrossRef]

59. Saphores, J.D.; Li, W. Estimating the value of urban green areas: A hedonic pricing analysis of the single-family housing market in Los Angeles, CA. Landsc. Urban Plan. 2012, 104, 373-387. [CrossRef]

60. Yamagata, Y.; Murakami, D.; Yoshida, T.; Seya, H.; Kuroda, S. Value of urban views in a bay city: Hedonic analysis with the spatial multilevel additive regression (SMAR) model. Landsc. Urban Plan. 2016, 151, 89-102. [CrossRef]

61. Povilanskas, R.; Armaitienè, A.; Breber, P.; Razinkovas-Baziukas, A.; Taminskas, J. Integrity of Linear Littoral Habitats of Lesina and Curonian Lagoons. Hydrobiologia 2012, 699, 99-110. [CrossRef]

62. Povilanskas, R.; Riepšas, E.; Armaitienè, A.; Dučinskas, K.; Taminskas, J. Shifting Dune Types of the Curonian Spit and Factors of Their Development. Balt. For. 2011, 17, 215-226.

63. Povilanskas, R.; Baghdasarian, H.; Arakelyan, S.; Satkūnas, J.; Taminskas, J. Secular Morphodynamic Trends of the Holocene Dune Ridge on the Curonian Spit (Lithuania/Russia). J. Coast. Res. 2009, 25, 209-215.

64. Povilanskas, R.; Armaitienè, A. Marketing of coastal barrier spits as liminal spaces of creativity. Procedia-Soc. Behav. Sci. 2014, 148, 397-403. [CrossRef]

65. Baltranaitè, E.; Jurkus, E.; Povilanskas, R. Impact of Physical Geographical Factors on Sustainable Planning of South Baltic Seaside Resorts. Baltica 2017, 30, 119-131. [CrossRef]

66. Rudis, V.A.; Gramann, J.H.; Rudell, E.J.; Westphal, J.M. Forest inventory and management based visual preference models of southern pine stands. For. Sci. 1988, 34, 846-883.

67. Roth, M.; Hildebrandt, S.; Röhner, S.; Tilk, C.; von Raumer, H.G.S.; Roser, F.; Borsdorff, M. Landscape as an area as perceived by people: Empirically-based nationwide modelling of scenic landscape quality in Germany. J. Digit. Landsc. Archit. 2018, 3, 129-137. 
68. Palmer, J.F. The contribution of a GIS-based landscape assessment model to a scientifically rigorous approach to visual impact assessment. Landsc. Urban Plan. 2019, 189, 80-90. [CrossRef]

69. Fischer, C.; Roth, M. Assessing visual landscape sensitivity towards wind turbines with a distance decay effect: An exploration of different GIS approaches. J. Digit. Landsc. Archit. 2021, 6, 148-162.

70. Chang Chien, Y.M.; Carver, S.; Comber, A. An exploratory analysis of expert and nonexpert-based landscape aesthetics evaluations: A case study from Wales. Land 2021, 10, 192. [CrossRef]

71. Dean, D.J.; Lizarraga-Blackard, A.C. Modeling the magnitude and spatial distribution of aesthetic impacts. Environ. Plan. B Plan. Des. 2007, 34, 121-138. [CrossRef]

72. Roth, M.; Gruehn, D. Visual landscape assessment for large areas using GIS, Internet surveys and statistical methodologies. Proc. Latv. Acad. Sci. A Humanit. Soc. Sci. 2012, 129-142.

73. Chhetri, P.; Arrowsmith, C. GIS-based modelling of recreational potential of nature-based tourist destinations. Tour. Geogr. 2008, 10, 233-257. [CrossRef]

74. Hull, R.B.; Stewart, W. Validity of photo-based scenic beauty assessments. J. Environ. Psychol. 1992, 12, 101-114. [CrossRef]

75. Pearson, E.S. The choice of statistical test illustrated on the interpretation of data classed in a $2 \times 2$ table. Biometrika 1947, 34, 139-167.

76. Gundumogula, M. Importance of Focus Groups in Qualitative Research. Int. J. Humanit. Soc. Sci. 2020, 8, $299-302$.

77. Pérez-Hernández, E.; Peña-Alonso, C.; Fernández-Cabrera, E.; Hernández-Calvento, L. Assessing the scenic quality of transgressive dune systems on volcanic islands. The case of Corralejo (Fuerteventura island, Spain). Sci. Total Environ. 2021, 784, 147050. [CrossRef]

78. Gupta, A.; Srivastava, A.; Anand, R.; Tomažič, T. Business Application Analytics and the Internet of Things: The Connecting Link. In New Age Analytics: Transforming the Internet through Machine Learning, IoT, and Trust Modeling; Shrivastava, G., Sheng-Lung, P., Bansal, H., Sharma, K., Sharma, M., Eds.; Apple Academic Press: Burlington, ON, Canada; Palm Bay, FL, USA, 2020; pp. 249-273.

79. Petrick, J.F.; Backman, S.J. Using square measures of perceived value to fill round holes in the service literature-Why product-based measures are inadequate for tourism research: A response to Al-Sabbahy, Ekinci, and Riley. J. Travel Res. 2004, 42, 429-431. [CrossRef]

80. Robert, S. Assessing the visual landscape potential of coastal territories for spatial planning. A case study in the French Mediterranean. Land Use Policy 2018, 72, 138-151. [CrossRef] 